NBER WORKING PAPER SERIES

\title{
THE GLOBAL PRODUCTIVITY SLUMP: COMMON AND COUNTRY-SPECIFIC FACTORS
}

\author{
Barry Eichengreen \\ Donghyun Park \\ Kwanho Shin \\ Working Paper 21556 \\ http://www.nber.org/papers/w21556 \\ NATIONAL BUREAU OF ECONOMIC RESEARCH \\ 1050 Massachusetts Avenue \\ Cambridge, MA 02138 \\ September 2015
}

This paper was prepared as background material for the Asian Development Outlook 2015 Update. We thank Yooran Shin and Jisoo Kim for their excellent research assistance, and the Asian Development Bank for financial support. The views expressed herein are those of the authors and do not necessarily reflect the views of the National Bureau of Economic Research.

NBER working papers are circulated for discussion and comment purposes. They have not been peerreviewed or been subject to the review by the NBER Board of Directors that accompanies official NBER publications.

(C) 2015 by Barry Eichengreen, Donghyun Park, and Kwanho Shin. All rights reserved. Short sections of text, not to exceed two paragraphs, may be quoted without explicit permission provided that full credit, including $\odot$ notice, is given to the source. 
The Global Productivity Slump: Common and Country-Specific Factors

Barry Eichengreen, Donghyun Park, and Kwanho Shin

NBER Working Paper No. 21556

September 2015

JEL No. E0,E1,O3

\begin{abstract} among the significant global factors.

Barry Eichengreen

Department of Economics

University of California, Berkeley

549 Evans Hall 3880

Berkeley, CA 94720-3880

and NBER

eichengr@econ.Berkeley.edu

Donghyun Park

Economics and Research Department

Asian Development Bank

Manila, Philippines

dpark@adb.org

Kwanho Shin

Korea University

Department of Economics

Seoul 136-701

Korea

khshin@korea.ac.kr
\end{abstract}

Productivity growth is slowing around the world. In 2014, according to the Conference Board's Total Economy Data Base, the growth of total factor productivity (TFP) hovered around zero for the third straight year, down from 1 per cent in 1996-2006 and 1/2 per cent in 2007-12. In this paper we identify previous episodes of sharp and sustained decelerations in TFP growth using data for a large sample of countries and years. TFP slumps are ubiquitous: we find as many as 77 such episodes, depending on definition, in low-, middle- and high-income countries. Low levels of educational attainment, unusually high investment rates and weak political systems are among the significant country-specific correlates of TFP slumps, while increases in risk (higher TED spreads) and energy-price shocks are 


\section{Introduction}

Productivity growth is slowing around the world. In 2014, according to the Conference Board's Total Economy Data Base, the growth of total factor productivity (TFP) hovered around zero for the third straight year, down from 1 per cent in 1996-2006 and 1/2 per cent in 2007-12. This is one of the most disturbing and, no doubt, important phenomena affecting the world economy.

In seeking to understand this problem, it is tempting to invoke the global financial crisis, which disrupted the availability of credit, which is important for innovation, and which slowed the growth of international trade, with which increases in productivity and technical efficiency are associated historically. But the slump in TFP growth is widespread; it is not limited to or even differentially evident in countries most directly affected by the financial crisis. In the advanced countries, where the deceleration in productivity growth predates the financial crisis, some observers have invoked the hypothesis of secular stagnation, suggesting that productivity growth has slowed because of a decline in innovation or, possibly, inadequate spending on the demand side (Summers 2014).

But the decline in TFP growth is not limited to the advanced countries plausibly subject to this secular-stagnation problem. TFP growth has also been falling in China. It is negative in Brazil and Mexico. For these countries it is tempting to invoke the so-called middle-income trap, where growth, including TFP growth, is thought to slow as former lowincome countries achieve middle-income status and are no longer able to boost productivity simply by shifting labor from agriculture to manufacturing.

Again, however, the deceleration in TFP growth is not limited to emerging markets that have attained middle-income status. TFP growth in 2014 was barely positive in India. It has declined and is near zero in a number of relatively poor countries that are still far from middle-income status. TFP growth fell in Sub-Saharan Africa from 1999-2006 to 2007-2012 and again in 2013-14. It fell in Russia, Central Asia, Southeastern Europe and Latin America as a whole. ${ }^{1}$ And, in addition, recall, there is the fact that the phenomenon is not limited to developing and emerging markets; it afflicts the advanced economies as well.

Interpreting this phenomenon is not easy. While it may be possible to get some purchase on the explanatory power of competing hypotheses by comparing and contrasting the extent of the TFP growth slowdown in different countries in recent years, this approach has limitations. It is not possible to distinguish the importance of global and country-specific factors, for example, since all countries experienced the same changes in the state of the global economy in, say, 2014. Limiting one's attention to the recent spate of TFP slumps does not enable one to gauge to what extent current trends are unprecedented or have been witnessed before. This approach does not permit more than crude conjectures about whether the current productivity slump will persist.

In this paper we seek to take advantage of the fact that there have been productivity slumps before. We build a comprehensive data base of a large number of countries, focusing on episodes in which the rate of TFP growth has declined. We look at the distribution of percapita incomes at which these slumps have occurred. We consider the distribution of TFP slumps over time. We then examine the global and country-specific correlates of these TFP slumps. Finally we inquire into the question of persistence; specifically, we ask whether it is possible to find cases where TFP growth rates, having declined, accelerate subsequently.

\footnotetext{
${ }^{1}$ Again according to the estimates of the Conference Board.
} 
The study closest to ours is Ferriera et al. (2010). Using a different methodology than ours, the authors identify breaks in TFP growth rates in a sample of 77 countries from 1950 to 2000. They find that breaks were mainly concentrated in the early 1970s in the advanced countries but that they have been much more diverse in terms of timing in developing countries. They interpret this as suggesting that slumps in TFP growth in the advanced countries are mainly associated with external (global) factors - in particular, with energy price shocks - whereas in developing countries TFP growth slowdowns are mainly attributable to country-specific sources.

The current paper is also related to our own earlier work on growth slowdowns (Eichengreen, Park and Shin 2012). But where in that earlier work we were concerned with slowdowns in the rate of growth of GDP, which can be rooted in slower growth of the capital stock, slower growth of the labor force, slower technical progress and other factors, here we focus exclusively on the rate of growth of TFP. ${ }^{2}$

The rest of this paper is organized as follows. Section 2 reviews the extensive if not entirely conclusive literature on productivity slowdowns, much of which was motivated by the productivity problems in the United States and to a lesser extent other advanced countries in the 1970s. Sections 3 and 4 then describe our data and empirical analysis, respectively. Section 4 , in concluding, attempts to draw out the implications.

\section{Previous Literature}

A large literature considers possible sources of the sharp slowdown in productivity growth affecting the U.S. economy in the 1970s. In an influential study summarizing the author's own extensive earlier research, Denison (1985) pointed to end of the reallocation of labor from low productivity agriculture and self-employment to higher productivity jobs, in manufacturing in particular, and to the negative impact of the early 1970s-recession on productivity growth. The association between TFP growth and employment in manufacturing is a well-known regularity, tracing back at least to Kuznets (1966). The association of TFP growth slowdowns with recessions is more controversial. First, there is the possibility that the decline in the level or rate of growth of TFP reflects mismeasurement - that it is really a decline in the effective capital stock due to lower utilization that is not captured by standard growth-accounting methods (Basu, Fernald and Kimball 2006). In addition, there is the fact that not all recessions are associated with slower productivity growth. The Great Depression of the 1930s famously saw an acceleration of TFP growth in the United States (Field 2012), consistent with the recessions-as-reorganizations view (Hall 1991, Caballero and Hammour 1994).

Subsequent authors emphasized the association between slower TFP growth and macroeconomic volatility generally, focusing on variables like the level and variability of inflation. Looking across countries, Lindbeck (1983) documented an association between macroeconomic volatility and TFP growth in the 1970. That slowdown and the rise in macroeconomic volatility certainty appear to coincide. But the hypothesis that the

\footnotetext{
${ }^{2}$ Where both Ferriera et al. (2010) and Eichengreen, Park and Shin (2012) look for significant breaks in the time series behavior of GDP, we identify those breaks differently. In addition, Ferriera et al. construct TFP by subtracting a weighted measure of investment from GDP, we use a more complex and hopefully more accurate measure of TFP as estimated directly in subsequent versions of the Penn World Tables. An alternative measure of TFP constructed by the Conference Board, referred to above, starts only in 1990. Our sensitivity analysis confirms that TFP measures by the Penn World Tables and the Conference Board are quite consistent with each other.
} 
association is causal can be questioned, since other factors affecting the economy negatively could have plausibly brought about slower TFP growth and higher inflation simultaneously.

Jorgenson, Gollop and Fraumeni (1987) emphasized declining (or more slowly rising) labor quality as a factor in the 1973-79 TFP growth slowdown. This period saw women and young workers with less human capital enter the U.S. labor force, where they went disproportionately into low-paying, relatively low productivity jobs. There may have also been some decline in the quality of education in the United States beginning in the 1960s. According to some authors, the observed decline in Standardized Achievement Test (SAT) scores is indicative of this tendency. But the accuracy of those SAT-based measures has been questioned. And whether this is properly viewed as an actual decline in TFP growth or growing mismeasurement of labor input (when the latter is not adjusted for quality) is debated.

In a classic contribution, Jorgenson (1984) showed that energy prices can affect TFP growth if technical progress is energy using (i.e. biased toward the use of energy). He confirmed the existence of this bias for the U.S. but found that the magnitude of the effect was small. A related literature explores the possibility that energy price volatility results in the obsolescence of a portion of the existing capital and perhaps, along with it, a portion of the stock of previously accumulated knowledge. However, Moomaw and Williams (1991) looked across U.S. states, which vary in their energy intensity, and found no impact on differential TFP growth slowdowns in the 1970s and after. Hulton, Robertson and Wykoff (1987) looked directly at the price of used capital equipment and found little evidence of an obsolescence effect.

Information technology (IT) is a prominent suspect in the recent productivity slowdown. Attributing a role to IT takes some ingenuity, however, since IT is popularly credited for the acceleration in productivity growth, most markedly in the U.S. but more generally, in 1995-2005 as well as being blamed for the subsequent slowdown. It could be that the development and diffusion of new IT come in waves or clusters, where a first wave was developed but not yet successfully deployed prior to 1995, while a second wave is being developed but has not yet been commercially applied since 2005. Consistent with this view, Fernald (2014) finds that the post-2004 slowdown in TFP growth in the U.S. is heavily concentrated in sectors that use IT intensively or produce it.

On the other hand, Carderelli, Roberto and Lusine Lusinyan (2015), looking across U.S. states, find no differences between IT intensive and other states in the extent of the TFP slowdown after 2005. Their analysis suggests, rather, that states with high educational attainment have tended to have higher and faster growing TFP in recent years. In their earlier study, Moomaw and Williams (1991) similarly found that differential state investments in education significantly shaped states' success in maintaining TFP growth.

The literature on other countries is equally extensive. A prominent case in point is Japan, where average TFP growth fell from $1.84 \%$ in the 1980 s to 0.42 per cent in the $1990 \mathrm{~s}$ and 0.16 per cent in the first decade of the $20^{\text {th }}$ century. Muto et al. (2013) emphasize the role of financial disruptions in preventing firms with high-productivity projects from accessing external finance. One might also point to the role of banks in keeping lowproductivity zombie firms alive. An awkward observation for this last hypothesis, however, is that many of these zombie firms were in sectors like real estate, construction, retail and wholesale, while the slowdown in TFP growth was most pronounced in manufacturing.

Fukao and Kwon (2005) therefore examine the role of R\&D spending on productivity growth. There is some decline in R\&D intensity in Japan, as elsewhere, starting in the early 
1990s, reflecting among other things weak demand growth, financial distress and creditmarket disruptions. Comin (2009) similarly notes that R\&D expenditures stopped growing in Japan in the 1990s, while the speed of diffusion of new technologies slowed down. More generally, the slowdown in TFP growth in Japan appears to have been most pronounced in firms and sectors with relatively low R\&D intensity. Kuroda, Motohashi and Shimpo (2007) blame Japanese underinvestment in IT for the failure of TFP growth to pick up after 1995 as quickly as in the United States. They find that TFP growth was maintained in the 1990s in Japan only in IT-using electrical machinery and communication services, "reflecting the IT revolution."

As for the persistence of the TFP slump into the subsequent period when Japanese investment in IT picked up, Nishimura and Shirai (2003) find some tendency for IT to have a negative indirect effect on productivity. In the past, they argue, the technological and managerial strengths of Japanese firms were based on learning by doing in the workplace. But as knowledge management systems improve as a result of IT and knowledge is easily transferred across international borders, Japan may no longer have the same advantage as before.

There is also some evidence for both Japan and Europe that the slump in TFP growth is greatest for sectors and countries whose international transactions have been growing most slowly. For Europe the evidence suggests that countries where the share of tradeables has fallen by less have done better in terms of maintaining earlier rates of TFP growth.

The literature on TFP growth in emerging markets is spottier, reflecting the limitations of the data. Young (1994) and Krugman (1994) famously argued that the problem of low TFP growth in East Asian emerging markets was of long standing, a conclusion challenged on grounds of mismeasurement by Hsieh (2002). More generally, there is no consensus on how TFP growth will develop in emerging markets, creating a temptation, as Tsounta (2014) notes, to extrapolate the experience of the recent past. In projecting future growth rates, Tsounta himself assumes that the rate of TFP growth experienced in the 200012 period will continue to prevail in coming years.

Other investigators have taken the available estimates at face value and considered trends and fluctuations of TFP growth rates over time. Kim (2001) compares changes in TFP growth between 1960-73 and 1973-94 across regions (advanced Europe and North America, emerging Latin America, South Asia and East Asia alike). According to his tabulations, every region other than South Asia and East Asia showed a marked decline between these periods (where TFP growth in South Asia had been very low, barely positive, in 1960-73, and where TFP growth in East Asia declined only slightly)

What general conclusions are to be drawn from these patterns? We now turn to this question, starting with some empirical regularities in the next section.

\section{Basic Patterns}

We take data on TFP growth from the Penn World Tables 8.1, the instalment that covers the period ending in 2011. This is the second PWT release including estimates of TFP. $^{3}$

We seek to isolate both episodes where TFP growth slows significantly and persistently as well as episodes where it first slows significantly and persistently but then recovers. Intuitively, the first set of TFP slumps is "permanent," while the second is

\footnotetext{
${ }^{3}$ PWT 8.1 also includes an alternative "welfare-based" TFP measures which we do not utilize here.
} 
"transitory." We consider all countries with per capita GDPs in purchasing power parity terms of at least $\$ 4,000$ in constant 2005 US dollars. Countries with very low incomes tend to have unusually volatile output and TFP growth rates, reflecting idiosyncratic countryspecific factors such as climatic variations and civil unrest. We therefore exclude them from our analysis.

We identify TFP slumps and recoveries using a methodology in the spirit of our earlier work on growth slowdowns. We consider successive 5, 7 and 10 year periods (alternatively) and isolate episodes where the growth rate of TFP was at least 1.0 per cent or 1.5 per cent lower (alternatively) on average in the second period than the first. In addition, to qualify as a TFP slump, TFP in the first of the two periods must have been growing at a respectable rate (where "respectable" is taken as the mean growth rate in the sample of countries and years).

Similarly, for accelerations we focus on observations where the growth rate of TFP averaged (at least) 1.0 or 1.5 per cent more in the second period than the first. Again, for an episode to qualify as a recovery, TFP in the second period had to be growing by at least the sample average.

In some cases this methodology identifies a string of consecutive years as TFP slumps (or accelerations). ${ }^{4}$ One way of dealing with this is to simply count each entry in this series as a slowdown year. The alternative is to use a Chow test for structural breaks to select one year of the series as "the TFP slump year. We consider both approaches in what follows.

For straightforward reasons, the shorter the period and lower the cut-off, the more slump and recovery episodes we identify. We identify 77 countries that have experienced a TFP slump when using the 5 year - 1 per cent criterion. By comparison, 52 countries qualify as having experienced TFP slumps when we use the most restrictive criterion of 10 years and a 1.5 per cent threshold. 75 countries experience a TFP acceleration in the 5 year -1 per cent case, compared to 43 when we consider 10 year periods and a 1.5 per cent threshold. Finally there are 66 countries where TFP growth first slows but then recovers according to the most permissive criterion and just 27 such countries according to the strictest criterion. Table 1 shows comparable numbers for all 6 definitions.

Readers may worry that we are simply capturing the same slowdowns in GDP growth as in Eichengreen, Park and Shin (2012), since TFP (as opposed to capital and labor input) is the component of gross output whose rate of increase often falls most abruptly when the rate of growth of aggregate output slows. In fact, although growth slowdowns and TFP slumps do sometimes coincide, there are also many instances where they do not. Recall for example, the Asian crisis in the late 1990s, following which the rate of GDP growth slowed noticeably across the region. In some countries, that slowing was associated with an abrupt downshift in the rate of growth of TFP, as we show. But in other instances it was associated instead with a downshift in the investment rate.

Consider for example our least demanding definition of TFP slowdowns: slowdowns of at least 5 year's duration in which TFP growth falls by 1 percentage point. We have a total of 1,052 country-year observations that qualify by these criteria. ${ }^{5}$ Ask now how many of these years are also categorized as a growth slowdown, and to bias the results in the direction

\footnotetext{
${ }^{4}$ In what follows we avoid repeating the "or accelerations" proviso for brevity.

${ }^{5}$ The number of observations is based on the approach where we include all consecutive years as TFP slumps.
} 
of overlap include also growth slowdowns in the preceding or successive year. The answer is 455 , less than a half of our TFP-slowdown country-year observations. ${ }^{6}$

Figures 1, 2 and 3 show histograms for TFP slumps, accelerations and recoveries (where, recall, a recovery is a slump followed by an acceleration) for the least restrictive definition, a 1 per cent deceleration over successive 5 year periods. For slumps (Figure 1),

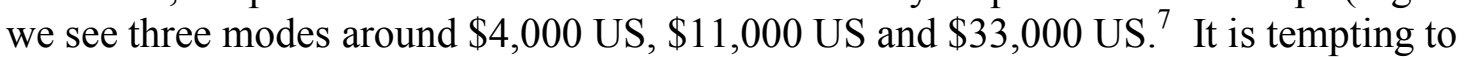
interpret these in terms of the productivity problems of poor countries (where productivity is affected by climatic variations, political turmoil etc.), of middle-income countries (where the challenges of transition from "extensive" to "intensive" growth are sometimes thought to create the danger of a middle-income trap), and of high-income countries (which have relatively high old-age dependency ratios and slowly growing populations and face the additional challenges of raising productivity when they are already at or near the technological frontier).

Figure 2, the histogram for accelerations, looks broadly similar in the sense that we have a first mode around the same level of per capita GDP as in Figure 1. The second mode appears to occur a little earlier, at around $\$ 10,000$ US. $^{8}$ The third mode occurs much earlier, at around $\$ 16,000-\$ 18,000$. Evidently accelerations are extremely unlikely once the per capita GDP exceeds $\$ 30,000$ US.

Figure 3 for TFP recoveries (cases where TFP growth first slumps and then recovers) shows a similar pattern as the figure for accelerations.

Figure 4 shows the distribution of TFP slumps by calendar year. Consistent with the earlier literature (and casual observation), a cluster of such episodes is evident in the early 1970 s at the time of the global productivity slowdown. We see another cluster in the late 1980 s and early 1990s, just prior to the 1995-2005 acceleration in productivity growth popularly associated with the IT revolution, and a third cluster in the second half of the 1990s in the run-up to the Asian crisis. ${ }^{9}$. There is then a fourth cluster in the mid-2000s, at the point in time when the 1995-2005 IT-related productivity surge petered out just prior to the global financial crisis. That many of these episodes are clustered at particular points in time is suggestive of a role for global factors in TFP-growth slowdowns.

For the advanced countries, in particular, it is tempting to associate productivity slowdowns with the oil shocks of the 1970s and early 1980s (as in much of the earlier literature). Column 1 in Table 2 confirms that a large majority of the advanced countries experienced productivity slowdowns in these two oil-shock periods. However, Column 2 also shows that slowdowns in this period account for only a minority of all productivity growth slumps experienced by the advanced countries between the 1950s and 2011. The story for the advanced countries, in other words, involves more than just oil shocks.

\footnotetext{
${ }^{6}$ The ratio is even lower (40.3 per cent) for 7 year periods and again when we use 10 year periods $((44.1$ per cent).

${ }^{7}$ While the third mode around $\$ 33,000$ is less visible for the most restrictive definition, the three modes are clearly visible in other five definitions including the one shown in Figure 1. See the online appendix for figures for the other five definitions.

${ }^{8}$ This is especially true if we look at Figure 2 (B) where we plot the density function based on the Chow test points.

${ }^{9}$ Of the 35 countries that experienced slowdowns in 1997-8, Asian countries in fact account for 6 observations: China, India, Indonesia, Philippines, Singapore, Taiwan. As noted above, there were also a number of other Asian countries that saw slower GDP growth following the crisis, but in their cases the growth slowdown reflected sharply lower investment rates rather than a downshift in TFP growth. In addition, Korea experienced slowdowns in 1989-91, Malaysia, in 1991-95, and Thailand in 1989-96.
} 
To gain a sense of which of these time spans and thresholds are most informative for empirical work, it helps to consider some well-known cases. As described above, Denison (1985) showed that TFP growth in the U.S. slowed in the late 1960s and early 1970s; more recently Fernald (2014) has established that TFP growth in the U.S. accelerated around 1995 and then slowed after 2005. We identify a TFP acceleration for the U.S. in 1995 only when we use 5-year averages with a 1 per cent cut-off. The 5-year average TFP growth rate before and after 1995 is 0.8 per cent and 2.0 per cent respectively. When we use 7-year averages, the TFP growth rate before and after 1995 is 0.8 and 1.5 per cent, respectively, rendering the difference less than the 1 per cent cut-off. When we use 10-year averages, the TFP growth rates are again 0.8 per cent and 1.5 per cent.

Interestingly, the 5-year 1-per cent cut-off places the earlier productivity slowdown for the U.S. as occurring in 1965-66, following the earlier post-World War II golden age of rapid productivity growth. ${ }^{10}$ Longer periods tend to place this earlier productivity slump as occurring somewhat later and perhaps in two steps; for example, the 10-year 1-per cent criterion identifies as TFP slump years 1966-8 and 1972-3. ${ }^{11}$

For China, where TFP growth is more volatile, the 5-year 1-per cent criterion picks up an acceleration in 1976-1983 coincident with the first wave of reforms, a slump in the second half of the 1980s, a recovery in the first half of the 1990s, another slump in the second half of that decade, and another recovery in the period 2001-4. The more restrictive 10-year 1.5 per cent criterion points only to an acceleration in 1978-1985 followed by a slump in 1993-1996. For Greece, another currently prominent case, the 10 -year 1.5 per cent criterion points to a long sequence of TFP slump years between 1965 and 1980 and then to a second slump in 2001. For Germany it produces a first TFP growth slowdown in 1960 (at the end of the "Wirtschaftswunder") and a second slump in 1972-79 (at the time of the 1970s productivity slowdown).

Although generalization is difficult, we are inclined to argue that less restrictive definitions (shorter periods distinguished by smaller changes in the average rate of TFP growth) are picking up more signal than noise (that they are likely to capture more of the episodes of interest).

\section{Circumstances in which TFP Slumps Occur}

We now attempt to shed light on the circumstances in which TFP slumps occur. We relate the incidence of slumps to a variety of country characteristics. Specifically, we consider per capita GDP in U.S. dollars (in levels and squared to pick up nonlinearities), the investment rate, economic openness as measured by the ratio of exports plus imports to GDP, a measure of real exchange rate undervaluation (the deviation of the real exchange rate from the value predicted by regressing the real rate on per capita GDP, demographic controls, and a vector of time dummies), years of schooling as a measure of educational attainment, the investment rate, the share of employment in manufacturing, two measures of the dependency ratio (old-age dependency and both old-age-and-youth dependency); two measures of political stability and development (how the country ranks in terms of rule of law and its Polity2 ranking), two measures of macroeconomic volatility (average inflation and the

\footnotetext{
${ }^{10}$ The analysis in Amador and Coimbra (2007) is consistent with this timing. Hulton (2001) similarly refers to the productivity slowdown in the U.S. that started in "the late 1960s or early 1970s." Phelps (2013) is another study of the U.S. that dates the country's productivity slowdown as commencing in the second half of the 1960s. ${ }^{11}$ Nordhaus (2004) regresses a long historical time series on TFP growth for the United States on rolling 5 year and 10 year dummy variables. His estimated coefficients are consistent with the picture of a two-step slowdown occurring in the late 1960 s and early 1970 s.
} 
volatility of inflation as captured by its coefficient of variation over the preceding five years), and two measures of energy prices (real gas and electricity costs). On the rationale for focusing on these variables, see the discussion in Section 2 above.

Table 3 shows average values for these variables in years when TFP growth begins to decelerate significantly, compared to other years. Sources and definitions are listed in Appendix A.

To avoid spurious precision, we include the year immediately preceding (t-1) and the year immediately following $(\mathrm{t}+1)$ the slump year in the treatment group (along with the year $\mathrm{t}$ in question). We also drop all data for years $t+2, \ldots t+5$ of the growth slowdown episode to contrast more clearly slump years and other years.

Starting with Panel A (all countries with per capita incomes above $\$ 4,000$ US and all consecutive TFP slowdown points), we see that per capita GDP is lower in slowdown cases than in the control group. However this pattern is reversed in the sample of relatively advanced countries (Panels $\mathrm{C}$ and $\mathrm{D}$ ). We also see that the educational attainment (as proxied by years of schooling) is significantly lower in slowdown cases than the control group, consistent with the idea that education is positive for productivity growth. In addition, investment is significantly higher in slowdown years, consistent with the notion of a tradeoff between the extensive and intensive margins of growth. Slowdown cases have also weaker political systems as measured by their Polity 2 scores. These differences will come through clearly in the regression analysis below.

TFP slowdowns episodes tend to be marked by lower energy costs than control group cases; this is inconsistent with the argument, deriving from the experience of the $1970 \mathrm{~s}$, that productivity slowdowns are associated with energy shocks, but consistent with the view that subsidized energy prices distort resource allocation and hinder productivity growth. Note, however, that our International Energy Agency data for energy costs, which vary by country, start only in 1979 and therefore exclude the first oil shock. They may reflect cross-country differences in taxes and subsidies as much (or more) than changing global energy prices. We will return to this below.

While old-age dependency ratios are significantly lower in TFP slump cases, overall dependency ratios tend to be higher. In addition, the openness of countries experiencing TFP slumps on average increases more rapidly than that of members of the control group. However this feature disappears in the sample of relatively advanced countries (Panels $\mathrm{C}$ and D).

Productivity slumps are also more likely in countries where the share of employment (or value-added) in manufacturing is high and growing slowly. They appear to be accompanied by higher rates of inflation but lower levels of inflation variability (less macroeconomic volatility, so measured), where recall that inflation variability here is the coefficient of variation of the inflation rate. We will want to examine the robustness of this contrast in what follows.

Panel B shows that these differences are broadly similar when we limit the treatment group to the TFP slump years identified by the Chow-test criterion. The patterns are also broadly similar when we limit the sample to countries with per capital GDP above $\$ 10,000$ US in 2005 prices - as in Panel C. The differences basically remain the same, with slump episodes displaying lower levels of educational attainment, higher investment rates, higher manufacturing employment shares, higher manufacturing value added, lower Polity 2 scores and lower energy prices. One important difference is that productivity slumps are more 
likely in countries where the rule-of law is low. In addition, productivity slumps are more likely in countries where the real exchange rate is more undervalued.

\section{Regression Analysis}

For purposes of regression analysis, the dependent variable takes a value of 1 for the three years centered on the year when a TFP slump begins. We drop all data pertaining to years $t+2, \ldots t+5$ of the TFP slump episode as a way of removing the remainder of the slump period to which either 0 or 1 may not be appropriately assigned. We include among the treatment-group cases all (consecutive) TFP slump years, and define slumps by considering successive 5 year periods and isolating episodes where the growth rate of TFP was at least 1.0 per cent lower on average in the second period than the first.

The control group then consists of the countries that did not experience a TFP slowdown in that same year. We also removed the observations for the 2007-2011 period entirely because that period is too short (four years rather than five) to determine whether they are in the treatment or control group. ${ }^{12}$

The sample again includes only countries with per capita GDP is above $\$ 4,000$ in constant 2005 US dollars, and oil exporting countries are also excluded. In alternative regressions focusing on advanced countries, we also consider only countries with per capita incomes above $\$ 10,000$ US. Probit regressions do not allow for country fixed effects, so we report logit regressions that do. ${ }^{13}$ (Results using probit are reported in the text where they make a significant difference - see Tables 6 and 7 - and a complete set of probit regression are in Appendix B.) A few of the estimates do not converge and are hence not reported. We also provide an analogous set of regressions for TFP accelerations and recoveries in Appendix C, although we focus in the text on TFP slumps as the phenomenon of special interest.

Regression results tending to be overly influenced by outliers, we removed outliers in openness and inflation, variables where the outlier problem was particularly severe. In the case of openness, we removed observations where the sum of imports and exports was more than 200 per cent of GDP. For inflation we removed observations where the annual inflation rate exceeded 50 per cent, while for inflation variability we removed cases where the coefficient of variation over the past five years exceeded 2. We return to the importance of extreme values of these variables further at the end of this section.

Consider the variables that are significant in one or more columns of Table $4 .{ }^{14}$ The probability of a TFP slowdown appears to peak (in Panel A) at a per capita income of $\$ 11,000-\$ 15,000$ US. ${ }^{15}$ This resembles an appropriately weighted average of the three modes at $\$ 4,000, \$ 11,000$ and $\$ 33,000$ apparent in the raw data.

In addition, years of schooling are negatively (and in some cases significantly) associated with the incidence of TFP slumps. This is consistent with the notion that countries

\footnotetext{
${ }^{12}$ We also removed the observations for the 2007-2011 period entirely when we report $t$ tests in Table 3.

${ }^{13}$ The advantage of probit regressions is robust standard errors, which are reported in parentheses. Note that logit regressions with fixed effects do not allow for robust standard errors.

${ }^{14}$ Note that a number of variables that uniformly enter with coefficients indistinguishable from zero have been removed from the table. Examples are the country-specific measures of energy costs (for which, recall, we have data only starting in 1979, which significantly reduces the sample size).

${ }^{15}$ These numbers are based on the probit regression results reported in Table B1. The peak is estimated to be at the minimum of per capita income level, $\$ 11,164$ in column 12 and at the maximum of per capita income level, $\$ 14,425$ in column 8 .
} 
that invest heavily in education are best able to continue moving up the technological ladder and to stay close to the technical frontier.

Strikingly, high investment rates are positively associated with the likelihood of TFP slumps. This is consistent with the idea that countries relying on brute-force capital accumulation may do so at the expense of productivity, insofar as extensive investment means investment in low-productivity, low-return projects. This observation is also consistent with worries that countries like China relying on investment for growth may be substituting capacity expansion for increases in efficiency.

There is also some evidence that the rate of increase in the share of employment in manufacturing in the preceding 5 years is associated with the likelihood of a TFP slump. Shifting labor from agriculture to manufacturing has been an important way of sustaining productivity growth historically. The higher the speed of the change in the past, the more difficult it becomes to raise it still further in both an economic and arithmetic sense. The patterns in Table 4 are broadly consistent with this view.

It would appear that countries with stronger, more contestable political systems (higher Polity2 scores) are less susceptible to TFP slumps. This is consistent with the idea that efficient political systems that give voice to stakeholders are better able to agree on reforms and policies that sustain productivity growth. The quality of political institutions comes through more clearly in Table 4, which includes developing countries, than in Table 5, which is limited to relatively advanced countries.

We also see in Table 4 some sign that more open economies are more susceptible to TFP slumps. This pattern comes through even more clearly when we controls for global factors (in Table 8). The intuition for this pattern is not obvious; we return to it below. Also surprising is that a number of plausible explanations for TFP slumps, such as macroeconomic variability, do not register significantly in these regressions.

In Table 5, where we focus on countries with per capita GDPs above $\$ 10,000$ US ("advanced economies" for present purposes), the results are generally consistent with those in Table 4. Here, however, the rate of increase in years of schooling in the preceding 5 years appears to be associated with less likelihood of a TFP slump. In addition, countries with high share of employment in manufacturing are more susceptible to TFP slumps. We will return to this in Table 8 where we consider global factors as well as country-specific factors.

In Tables 6 and 7 we analyse the impact of openness and macroeconomic volatility a bit further. In Table 6 we remove very high values of openness, cases where the sum of export plus imports exceeds 80 per cent of GDP. ${ }^{16}$ Now the coefficient on openness is negative and occasionally significant, not positive and significant as before. ${ }^{17}$ It would appear that more open economies, where international competition is more intense, are less prone to TFP slumps up to a threshold level, but above that level any additional benefit of openness, in terms of TFP growth resiliency, disappears.

In Table 7 we also remove high values of inflation variability, where the coefficient of variation of inflation is greater than $0.5 .^{18}$ Now the effect of inflation variability is positive and often highly significant, as if macroeconomic volatility makes TFP slowdowns more

\footnotetext{
${ }^{16}$ This reduces the number of observations for openness from 1,604 to 1,263.

${ }^{17}$ One column is missing because the estimates do not converge.

${ }^{18}$ This reduces the number of observations for inflation variability from 1,923 to 1,118 .
} 
likely. ${ }^{19}$ It would appear that volatility makes TFP slowdowns more likely as it rises up to a threshold level, but above that level its impact, like that of openness, vanishes.

The year fixed effects, when included, are jointly significant. They are telling us that global (as opposed to the country-specific factors included in the specifications) are important in helping to explain the incidence of productivity slumps. In Figures 5-6 and Table 8 we therefore consider the role of global factors more closely, focusing on world oil prices, world trade growth, LIBOR and the TED spread. The increase in global oil prices and world trade are shown in Figure 5, while LIBOR and the TED spread are shown in Figure 6.

The problem with analysing factors that vary over years but not across countries is that we are forced to remove the time fixed effects, creating the danger that our global factors may also be picking up time-varying, country-invariant omitted factors. Be that as it may, Table 8 shows a higher TED spread is positively associated with the incidence of TFP slumps. This result is striking in that the prominent instance of higher TED spreads, in the global financial crisis, is not considered here because the last slump year considered in our analysis is 2006 , given the five-year window.

In addition the coefficient on the rate of change of world oil prices is positively and significantly associated with the incidence of TFP slumps, consistent with the oil-shock interpretation of the 1970s and early-1980s productivity slowdowns. Note however that this result is not robust to including the full set of controls.

More puzzling is that world trade growth is positively and significantly associated with TFP slumps; it could be that world trade is standing in for the global business cycle and that TFP growth tends to weaken around the business cycle peak.

The other country-specific effects are unchanged with one notable exception. A high manufacturing employment share now appears to make a TFP slump less likely, at least for countries with per capita GDPs above $\$ 10,000$ US. This is consistent with the notion that, for advanced countries, a TFP slowdown is less likely as long as the share of the high-growing manufacturing sector is large.

It is natural to hypothesize that global factors will appear even more important once we have the data needed to treat 2007-12 as a slump period (recall that our Penn World Tables data, on which we rely for estimates of TFP, currently end in 2011). For the moment, what we can do is examine successive four year rather than five year periods. ${ }^{20}$ When we do, it turns out that fully $5.7 \%$ of total TFP slowdowns occur in 2007, which becomes the mode of the distribution of TFP slumps by calendar year. Once the large number of slowdowns in 2007 is added, the coefficient on LIBOR becomes positive and significant. The coefficient on the TED spread remains positive and is now more consistently significant than before. There is more evidence that oil shocks are significant. Reassuringly, world trade growth, with its peculiar sign, is no longer significant in the specifications in Table $8 .^{21}$

\section{Conclusion}

Slowing total factor productivity growth is raising concern around the world. After running at approximately 1 per cent per annum worldwide in the decade leading up to the

\footnotetext{
${ }^{19}$ One column is again missing because the estimates do not converge.

${ }^{20}$ The worry being, of course, that the shorter the period the greater the likelihood that what we are picking up is the cyclical behavior of productivity rather than secular TFP slumps.

${ }^{21}$ Previously, recall, world trade growth entered positively. That positive effect now disappears since world trade plummeted in 2009 .
} 
global financial crisis, TFP growth fell sharply and has now dropped to zero, where it has remained for three years. This phenomenon is evident in advanced countries like the U.S. and UK as well as in emerging markets like China, Brazil and Mexico. It is evident in Latin America, Southeast Europe and Central Asia. Discussion of these troubling trends is organized under a number of headings. These include the secular stagnation hypothesis, the question of whether the global financial crisis has permanently damaged the growth capacity of the world economy, and whether the heyday of emerging markets is over. These are without doubt the critical debates of our day.

The key questions are whether this phenomenon of sharply lower productivity growth is unprecedented, whether it is likely to last, which countries are most susceptible, and what if anything can be done about it. To shed light on the answers, we have isolated TFP growth slumps in countries with per capita GDPs of at least $\$ 4,000$ US (2005 prices) since the 1950s. It turns out that productivity slumps, defined as episodes when the rate of TFP growth fell sharply and persistently, are far from unprecedented. We have identified such episodes in the first half of the 1970s (the period commented upon most extensively in the literature on this subject) but also in the late 1980s and early 1990s, in the late 1990s, and on the eve of the global financial crisis.

We have identified TFP slumps in low-, middle- and high-income countries alike. Specifically, we observe clusters at per capita incomes of $\$ 4,000, \$ 11,000$ and $\$ 33,000$. Evidently, no country, rich or poor, and no period of time are immune from the risk of productivity slumps.

Our statistical analysis also points to policies that should be pursued and others best avoided by countries seeking to minimize this risk. We find a negative association between the incidence of TFP slumps and educational attainment as measured by average years of schooling. Countries with stronger political systems as measured by their Polity 2 scores are less susceptible to TFP slumps. In contrast, countries with high investment shares of GDP are more susceptible to TFP slumps, consistent with a tradeoff between extensive and intensive growth that places a priority on, respectively, capacity expansion and productivity growth.

The distinction between global and country-specific correlates of TFP growth slowdowns is clearly important. Recall how the oil shocks of the 1970s and 1980s and the global financial crisis (as well as other periods marked by sharply higher TED spreads) adversely affected the productivity of all countries, although some countries were hit harder than others. By the same token, the information and communication technology revolution of the 1990s contributed to higher productivity across the world.

While TFP slumps affect rich and poor countries alike, it is nonetheless useful to distinguish different groups of countries by their level of per capita income, for the nature of productivity slumps is likely to differ across countries at different income levels. For example, in middle-income countries slower TFP growth is likely to be associated with the process of reallocation of labor from agriculture to manufacturing having run its course. Productivity slumps in high-income countries, in contrast, are likely to be associated with the transition to services, where productivity gains are more difficult to achieve.

Slowing TFP growth is especially worrisome for China and developing Asia generally. Sustained rapid growth has transformed Asia from a predominantly low-income to an increasingly middle-income region. While the transition from low to middle income was driven to a large part by investment and factor accumulation, the more challenging transition 
from middle income to high income typically depends to a greater extent on improving productivity.

If the region is to continue growing, productivity growth will have to play a larger role in the future, given rapid population ageing and much of Asia's gloomy demographic prospects. While Asia reaped a sizable demographic dividend in the past, the region as a whole is now experiencing population aging. East Asia in particular is suffering the fallout of a sharp decline in fertility and strong wage pressures are emerging in parts of China.

Moreover, the transformation of developing Asia, especially East Asia, from a capitalscarce to a capital-abundant region - the legacy of the high-saving, high-investment paradigm - implies that the marginal returns to physical capital accumulation will decline. TFP growth will thus be vital. Asia's rapid technological catch-up in the past means that further technological progress will have to rely more on indigenous innovation.

Perhaps our most widely relevant finding is the need for strong political systems. For poor countries, TFP slumps and economic stagnation more generally are often associated with poor governance - i.e. ineffective governments that fail to build schools, hospitals, and roads. In the U.S., to take a very different case, polarized politics are blocking sensible debate on immigration reform, even though immigrants and their reservoir of entrepreneurial energy have contributed importantly to U.S. productivity and economic growth. TFP slumps are not pre-determined, and there is significant scope for sound policies and institutions to prevent or arrest them.

The determinants of productivity growth and productivity slumps are notoriously elusive. It follows that the patterns described here are necessarily suggestive. There is no guarantee that countries investing heavily in education, avoiding excessive investment, or developing relatively strong political systems will necessarily avoid TFP slumps. The good news is that there are in the historical record not just TFP growth slowdowns but also TFP growth accelerations and even recoveries (accelerations following slumps). Whether such accelerations and recoveries are now on the horizon only time will tell. 


\section{References}

Amador, Joao and Carlos Coimbra (2007), "Total Factor Productivity Growth in the G7 Countries: Different or Alike,” Working Paper no. 9/2007, Estudos e Documentos de Trabalho, Banco de Portugal (April).

Basu, Susanto, John Fernald and Miles Kimball (2006), “Are Technology Improvements Recessionary?” American Economic Review 96, pp.1418-1448.

Caballero, Ricardo and Mohamed Hammour (1994), "The Cleansing Effect of Recessions," American Economic Review 84, pp.1350-1368.

Carderelli, Roberto and Lusine Lusinyan (2015), "U.S. Total Factor Productivity Slowdown: Evidence from U.S. States," IMF Working Paper 15/116 (May).

Comin, Diego (2009), "An Exploration of the Japanese Slowdown during the 1990s," Working Paper 09-065, Harvard University.

Conference Board (2015), "Global Productivity Growth Stuck in the Slow Lane with No Recovery in Sight," Total Economy Database - Key Findings, New York: Conference Board.

Denison, Edward (1985), Trends in American Economic Growth 1929-82, Washington, D.C.: Brookings Institution.

Eichengreen, Barry, Donghyun Park and Kwanho Shin (2012), "When Fast-Growing Economies Slow Down: International Evidence and Implications for China," Asian Economic Papers 11, pp.42-87.

Fernald, John (2014), "Productivity and Potential Output Before, During and After the Great Recession," NBER Working Paper no.20248 (June).

Ferriera, Pablo, Antonio Galvao, Fabio Reis Gomez and Samuel Pesoa (2010), "The Effects of External and Internal Shocks on Total Factor Productivity," unpublished manuscript, Getulio Vargas Foundation.

Field, Alexander (2012), A Great Leap Forward: 1930s Depression and U.S. Economic Growth, New Haven: Yale University Press.

Fukao, Kyoji and Hyeog Kwon (2005), "Why Did Japan's TFP Growth Slow Down in the Lost Decade? An Empirical Analysis Based on Firm-Level Data of Manufacturing Firms," RIETI Discussion Paper no.05-E-004 (February).

Hall, Robert (1991), "Recessions as Reorganizations," NBER Macroeconomics Annual.

Hsiah, Chang-Tai (2002), "What Explains the Industrial Revolution in East Asia? Evidence from Factor Markets," American Economic Review 92, pp.502-526.

Hulton, Charles (2001), “Total Factor Productivity: A Short Biography,” in Charles Hulten, Edwin Dean and Michael Harper (eds), New Developments in Productivity Analysis, Chicago: University of Chicago Press, pp.1-54.

Hulton, Charles, James Robertson and Frank Wykoff (1987), "Energy, Obsolescence and the Productivity Slowdown," NBER Working Paper no.2404 (October).

Jorgenson, Dale (1984), "The Role of Energy in Productivity Growth," American Economic Review 74, pp.26-30. 
Jorgenson, Dale, Frank Gollop and Barbara Fraumeni (1987), Productivity and U.S. Economic Growth, Cambridge, Mass.: Harvard University Press.

Kim, Jong-Il (2001), “Total Factor Productivity Growth in East Asia: Implications for Future Growth," unpublished manuscript, Dongguk University Seoul.

Krugman, Paul (1994), “The Myth of Asia's Miracle,” Foreign Affairs 73, pp.62-78.

Kuroda, Masahiro, Kazuyuki Motohashi and Kazushige Shimpo (2007), "Investing Productivity Slowdown in the 1990s by using the KLEM Database in Japan," in Dale

Jorgenson, Tasahiro Kuroda and Kazuyuki Motohashi (eds), Productivity in Asia: Economic Growth and Competitiveness, Cheltenham: Edward Elgar, pp.7-26.

Kuznets, Simon (1966), Modern Economic Growth: Rate Structure and Spread, New Haven: Yale University Press,

Lindbeck, Assar (1983), "The Recent Slowdown of Productivity Growth,” Economic Journal 93, pp.13-34.

Moomaw, Ronald and Martin Williams (1991), "Total Factor Productivity Growth in Manufacturing : Further Evidence from the States," Journal of Regional Science 31, pp.1734.

Muto, Ichiro, Nao Sudo and Shunichi Toneyama (2013), "Productivity Slowdown in Japan's Lost Decades: How Much of It is Attributed to Financial Factors?" unpublished manuscript, Bank of Japan and Boston College (July).

Nishimura, Kiyohiko and Masato Shirai (2003), "Can Information and Communication Technology Solve Japan's Productivity Slowdown Problem?” Asian Economic Papers 2, pp.86-113.

Nordhaus, William (2004), "Retrospective on the 1970s Productivity Slowdown," NBER Working Paper no.10950 (December).

Phelps, Edmund (2013), Mass Flourishing, Princeton: Princeton University Press.

Summers, Lawrence (2014), "U.S. Economic Prospects: Secular Stagnation, Hysteresis, and the Zero Lower Bound," Business Economics 49, pp.65-73.

Tsounta, Evridiki (2014), "Slowdown in Emerging Markets: Sign of a Bumpy Road Ahead?" IMF Working Paper 14/205 (November).

Young, Alwyn (1994), "Lessons from the East Asian NICS: A Contrarian View," European Economic Review 38, pp.964-973. 
Figure 1. TFP Slumps

(A) Countries Whose Per Capita GDP is above $\$ 4,000$ : Consecutive Points

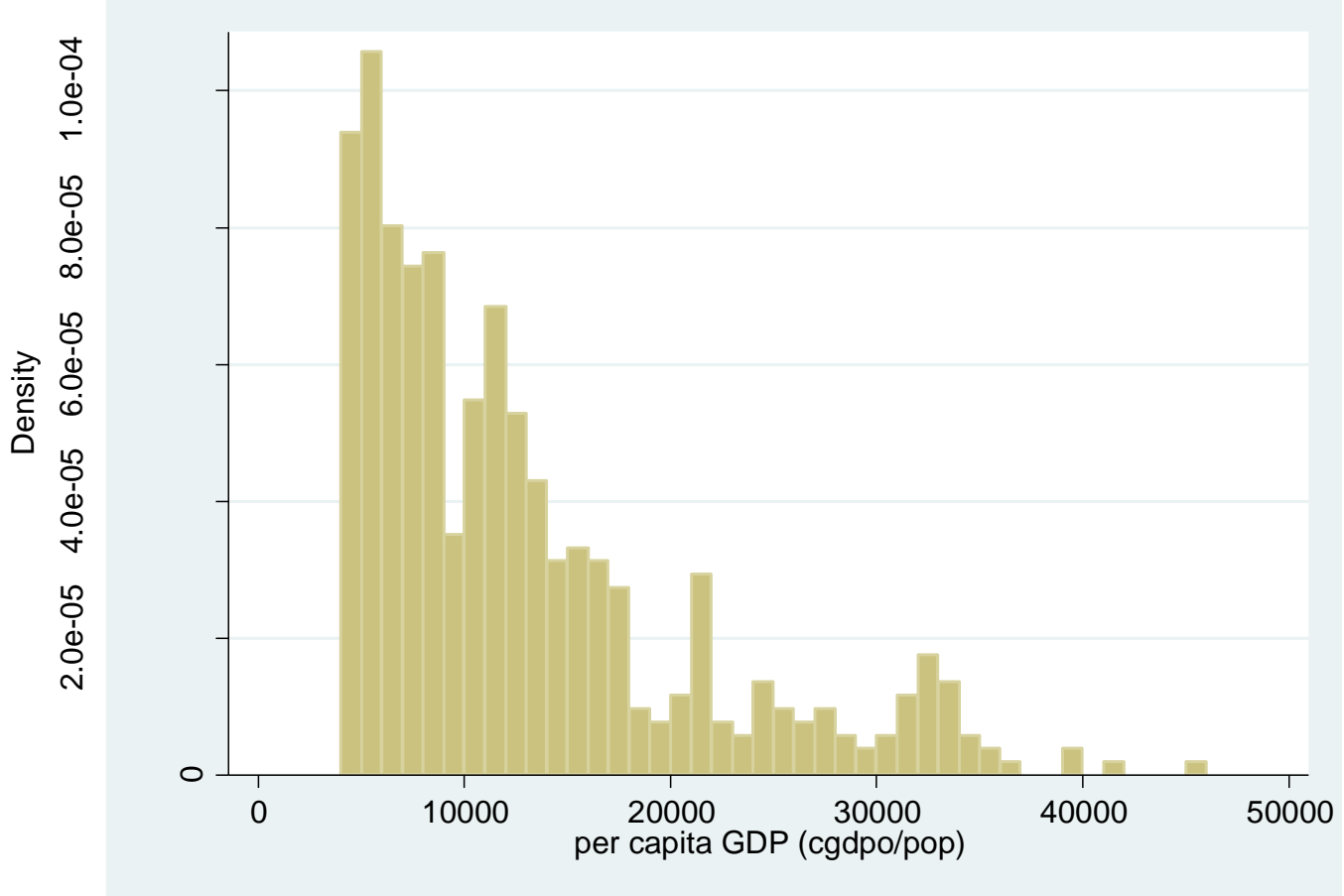

(B) Countries whose per capita GDP is above $\$ 4,000$ : Chow Test Points

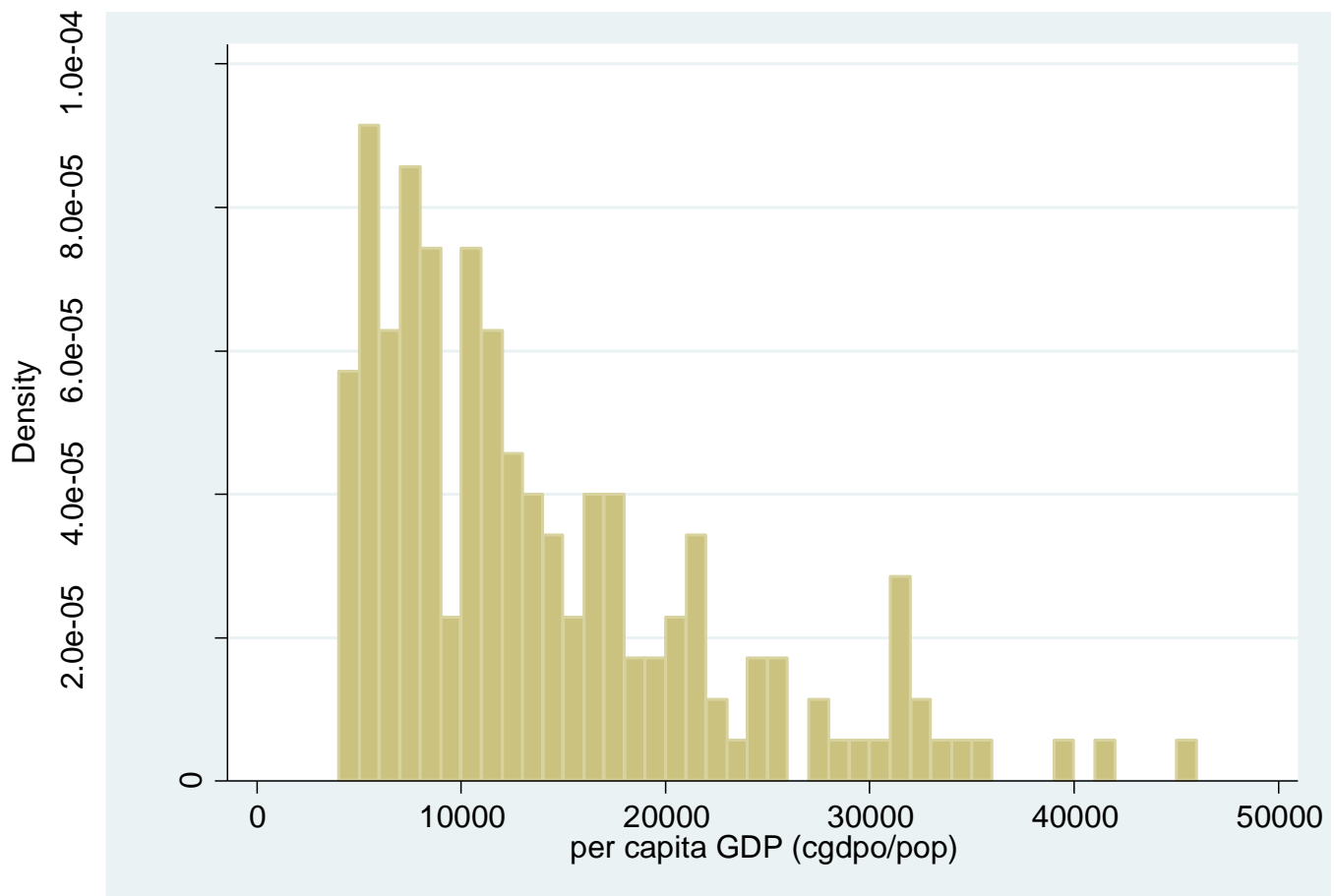

Note: Panel (A) shows the frequency distribution of all consecutive slumps by per capita income, while Panel (B), the same frequency distribution after only one slowdown is selected out of the consecutive slumps by employing a Chow test for structural breaks. We define slumps by considering successive 5 year periods and isolating episodes where the growth rate of TFP was at least 1.0 per cent lower on average in the second period than the first. Countries whose per capita GDP is below $\$ 4.000$ are removed in both graphs. Oil countries are not included. 
Figure 2. TFP Accelerations

(A) Countries Whose Per Capita GDP is above $\$ 4,000$ : Consecutive Points

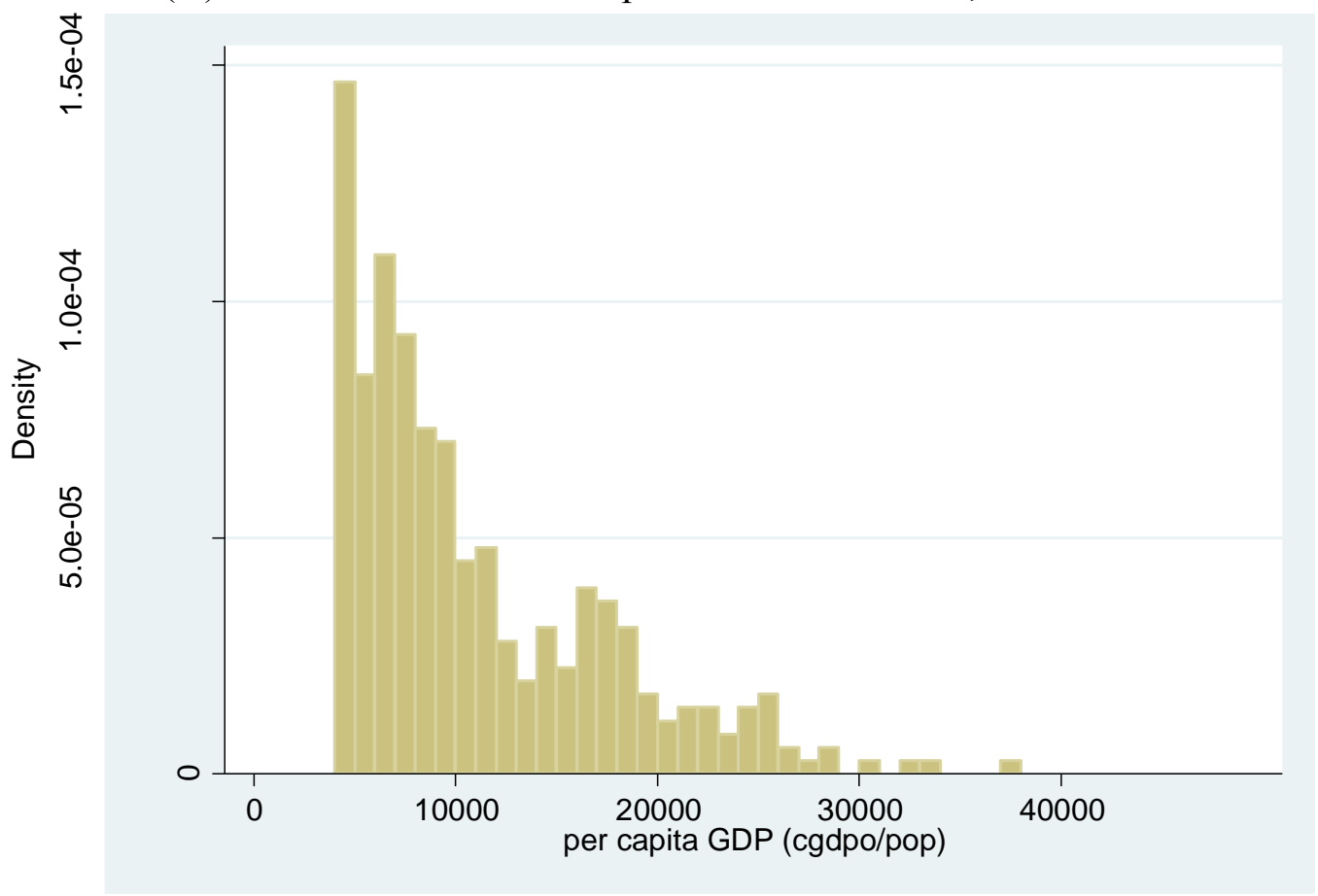

(B) Countries whose per capita GDP is above $\$ 4,000$ : Chow Test Points

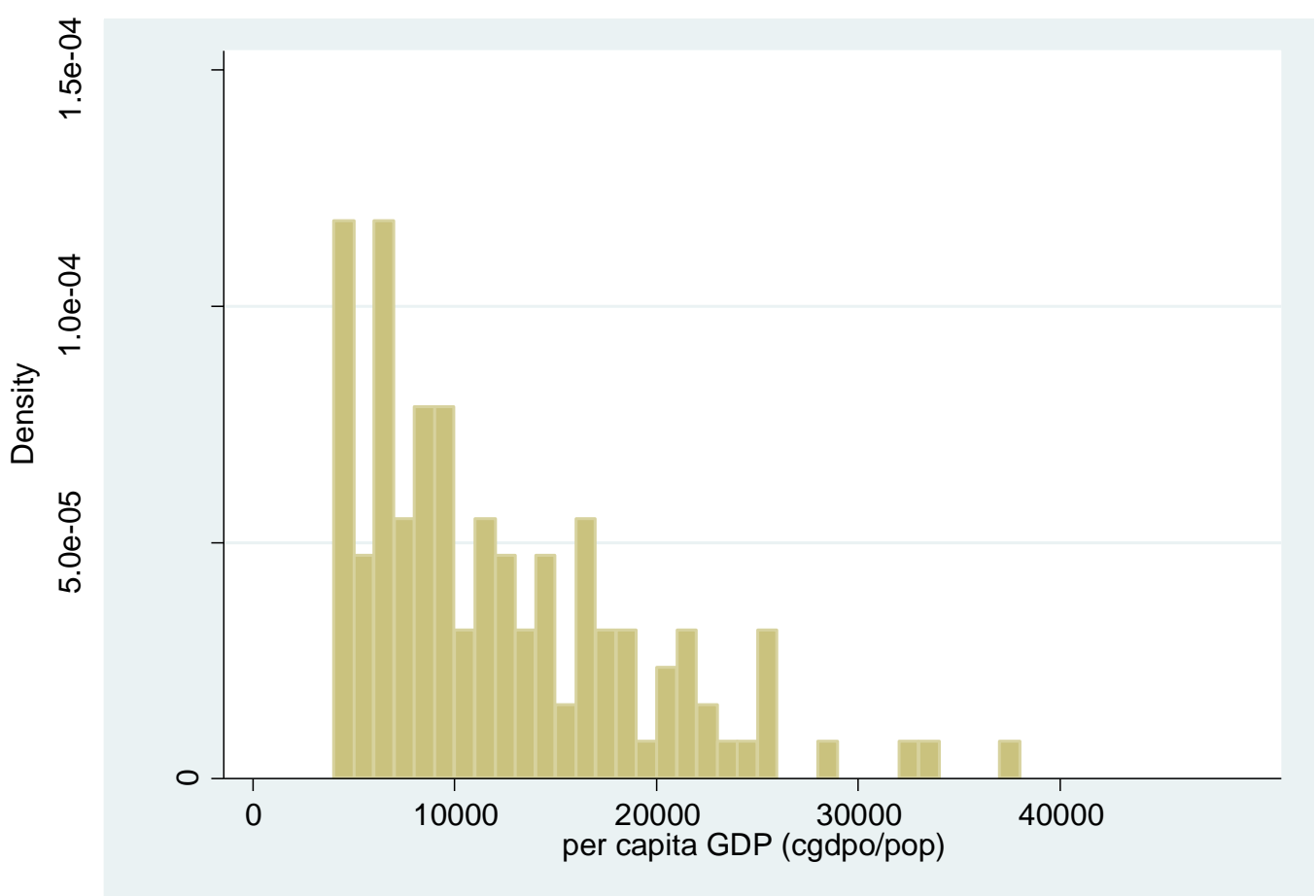

Note: Panel (A) shows the frequency distribution of all consecutive accelerations by per capita income, while Panel (B), the same frequency distribution after only one acceleration is selected out of the consecutive accelerations by employing a Chow test for structural breaks. We define TFP accelerations by considering observations where the growth rate of TFP averaged at least 1.0 per cent more in the second period compared to the first. Countries whose per capita GDP is below $\$ 4.000$ are removed in both graphs. Oil countries are not included. 
Figure 3. TFP Recoveries

(A) Countries Whose Per Capita GDP is above $\$ 4,000$ : Consecutive Points

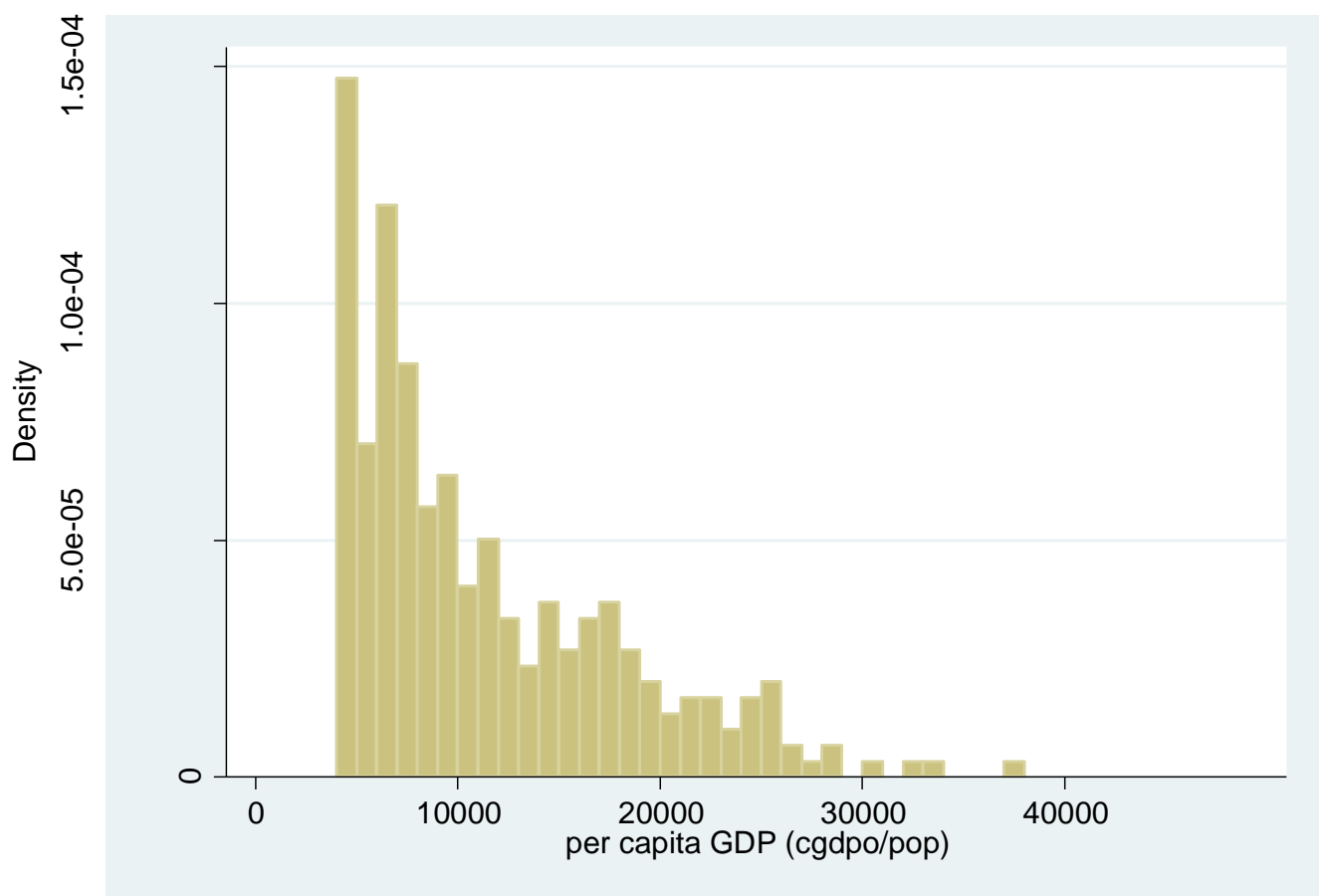

(B) Countries whose per capita GDP is above $\$ 4,000$ : Chow Test Points

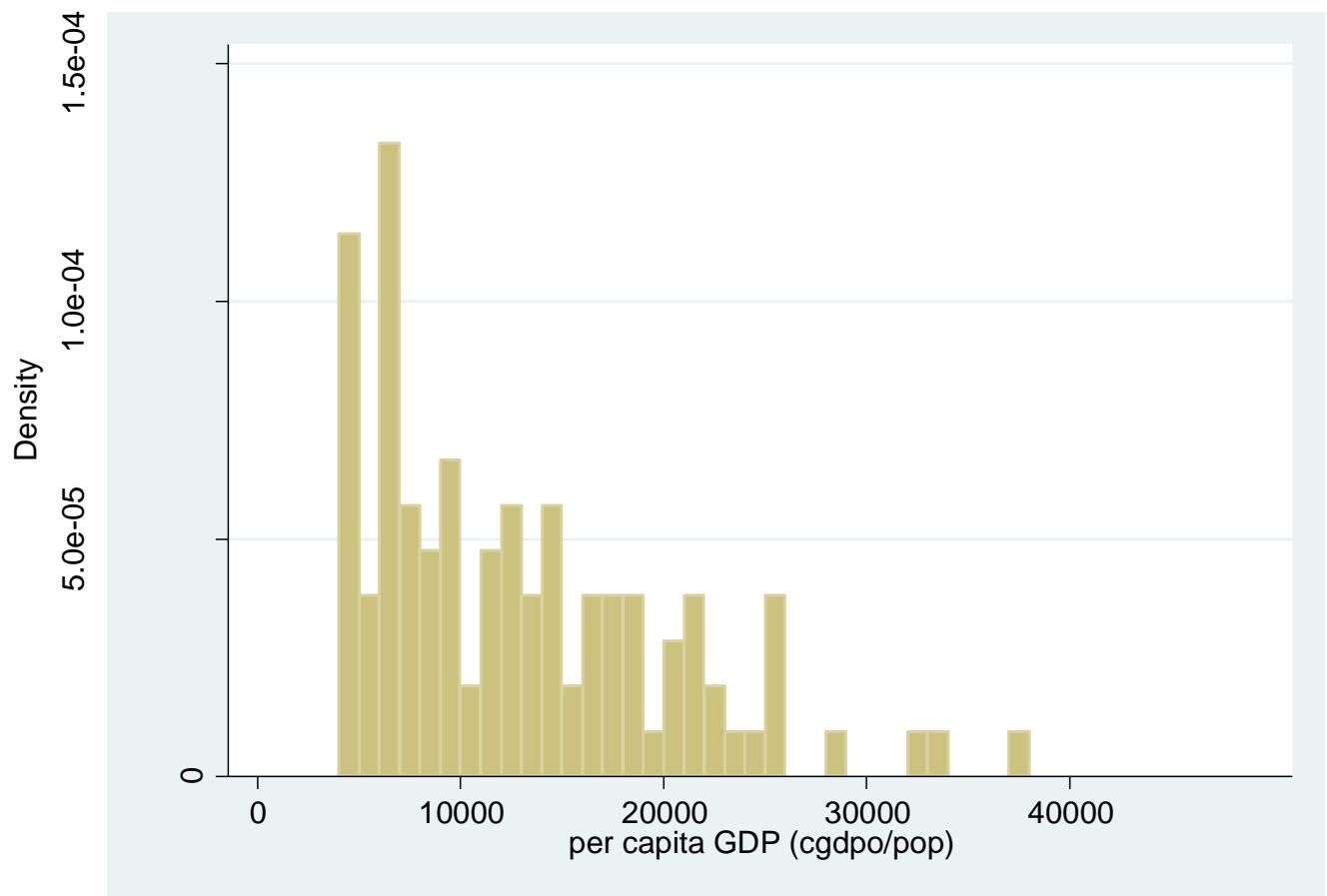

Note: Panel (A) shows the frequency distribution of all consecutive recoveries by per capita income, while Panel (B), the same frequency distribution after only one recovery is selected out of the consecutive recoveries by employing a Chow test for structural breaks. We define TFP recoveries in the same way as accelerations, but to qualify for a recovery, we require another condition that the particular country should experience a slowdown beforehand. Countries whose per capita GDP is below $\$ 4.000$ are removed in both graphs. Oil countries are not included. 
Figure 4. Years TFP Slumps Started

(A) Countries Whose Per Capita GDP is above $\$ 4,000$ : Consecutive Points

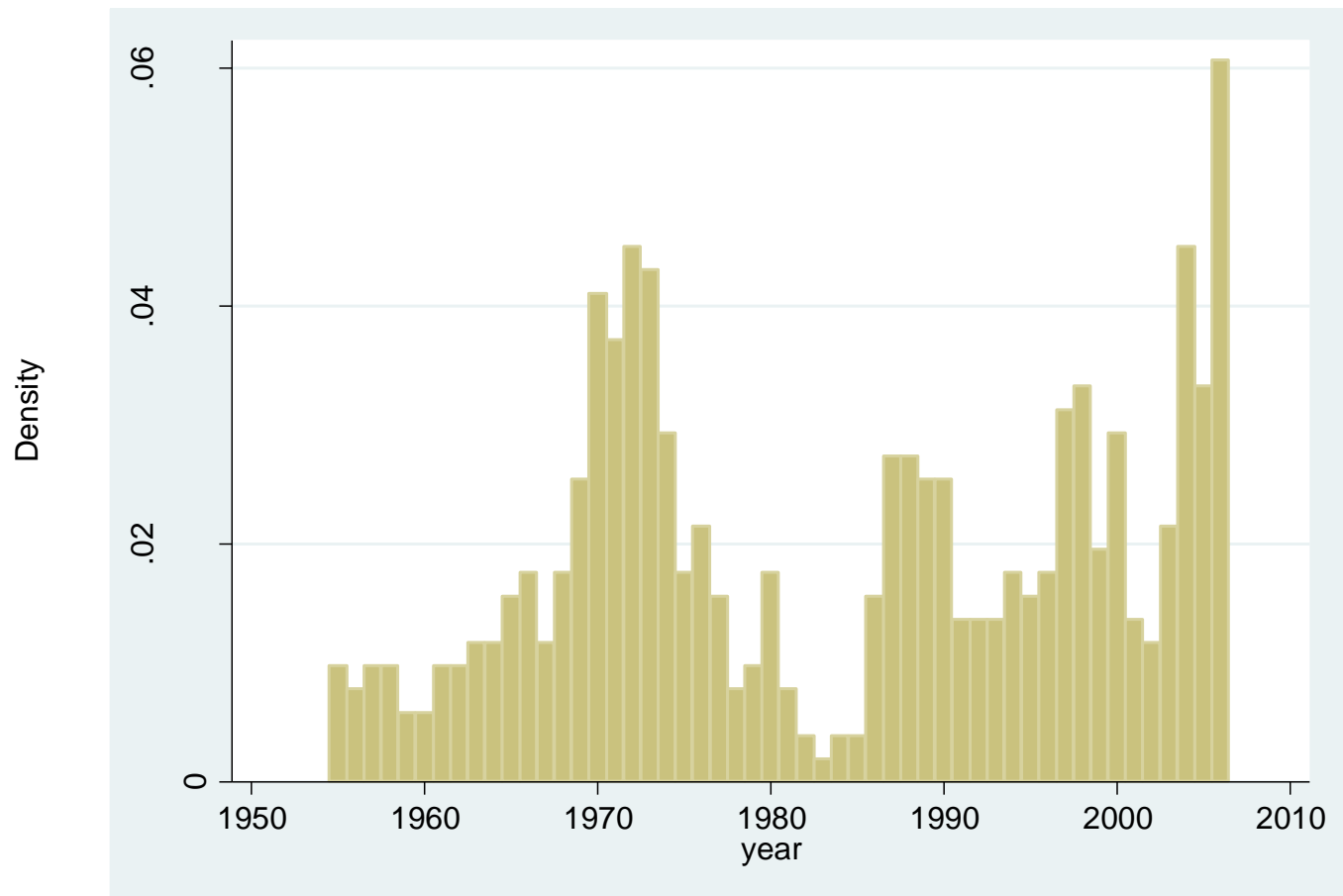

(B) Countries whose per capita GDP is above $\$ 4,000$ : Chow Test Points

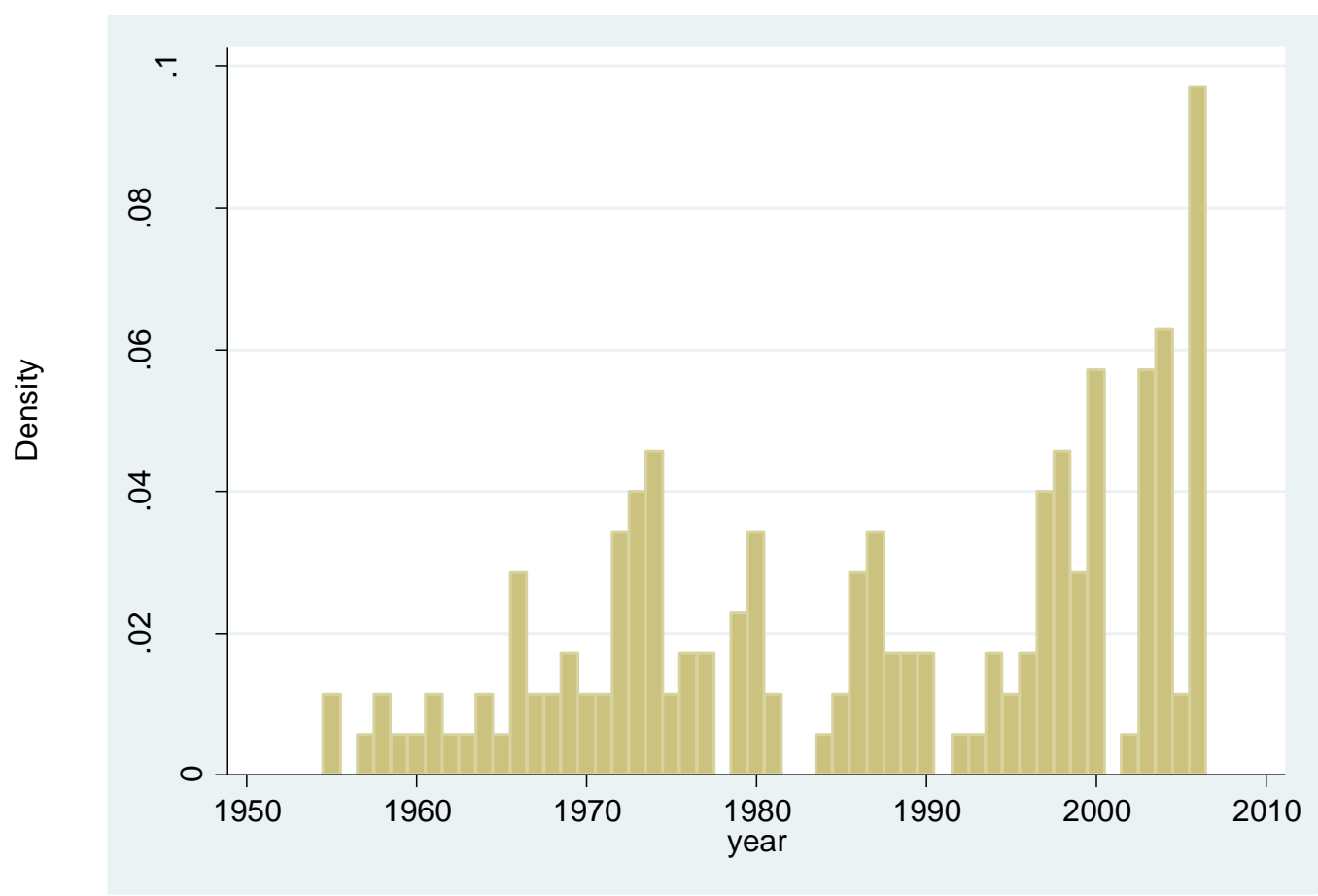

Note: The bars indicate the frequency distribution of years when a TFP slump began. We define slowdowns by considering successive 5 year periods and isolating episodes where the growth rate of TFP was at least 1.0 per cent lower on average in the second period than the first. A Chow test episode is selected out of the consecutive slowdowns by employing a Chow test for structural breaks. Oil countries are not included. 
Figure 5. Years TFP Slumps Started and Growth Rates of Oil Prices and World Trade

(A) Countries Whose Per Capita GDP is above $\$ 4,000$ : Consecutive Points

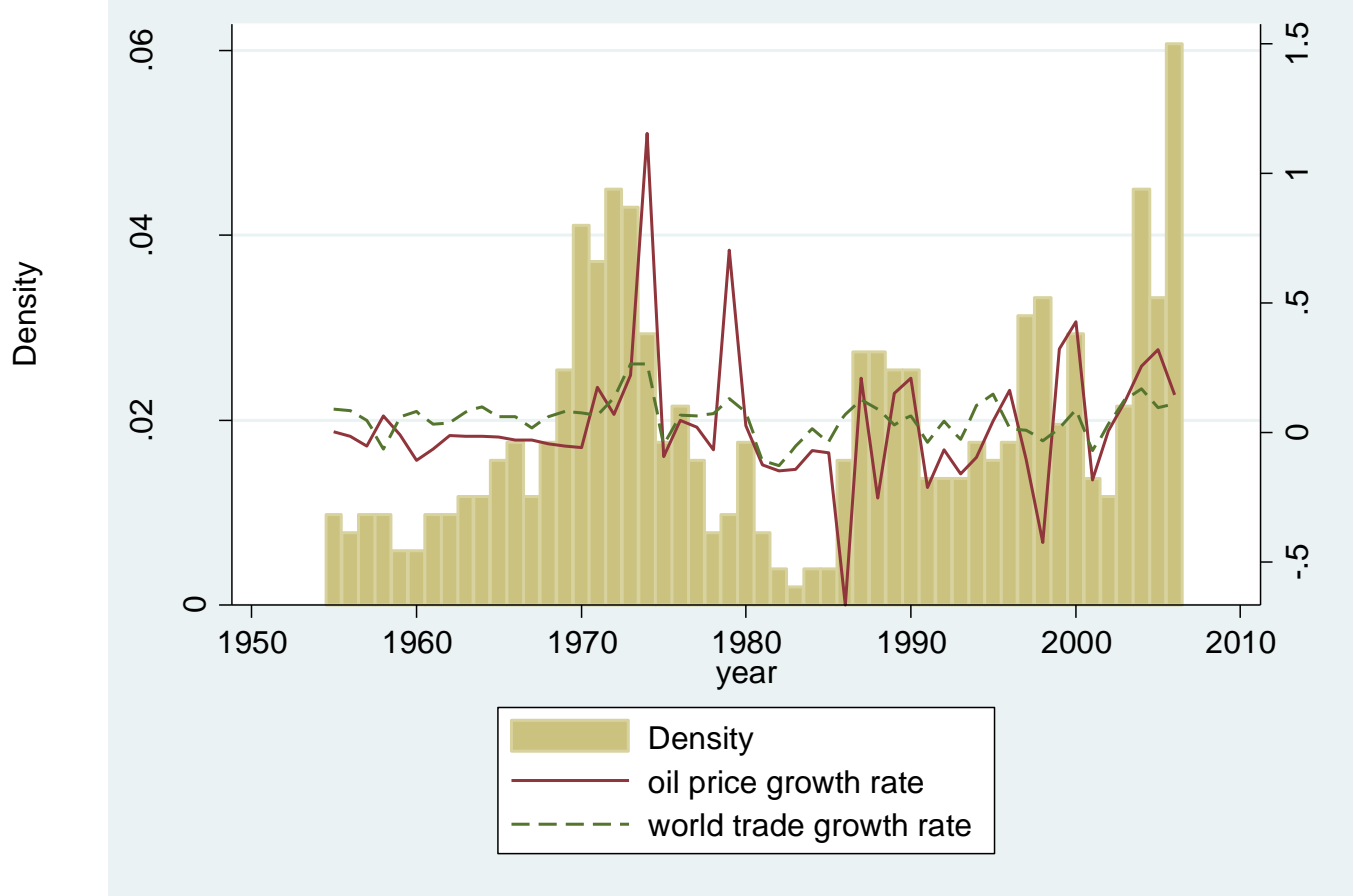

(B) Countries whose per capita GDP is above $\$ 4,000$ : Chow Test Points

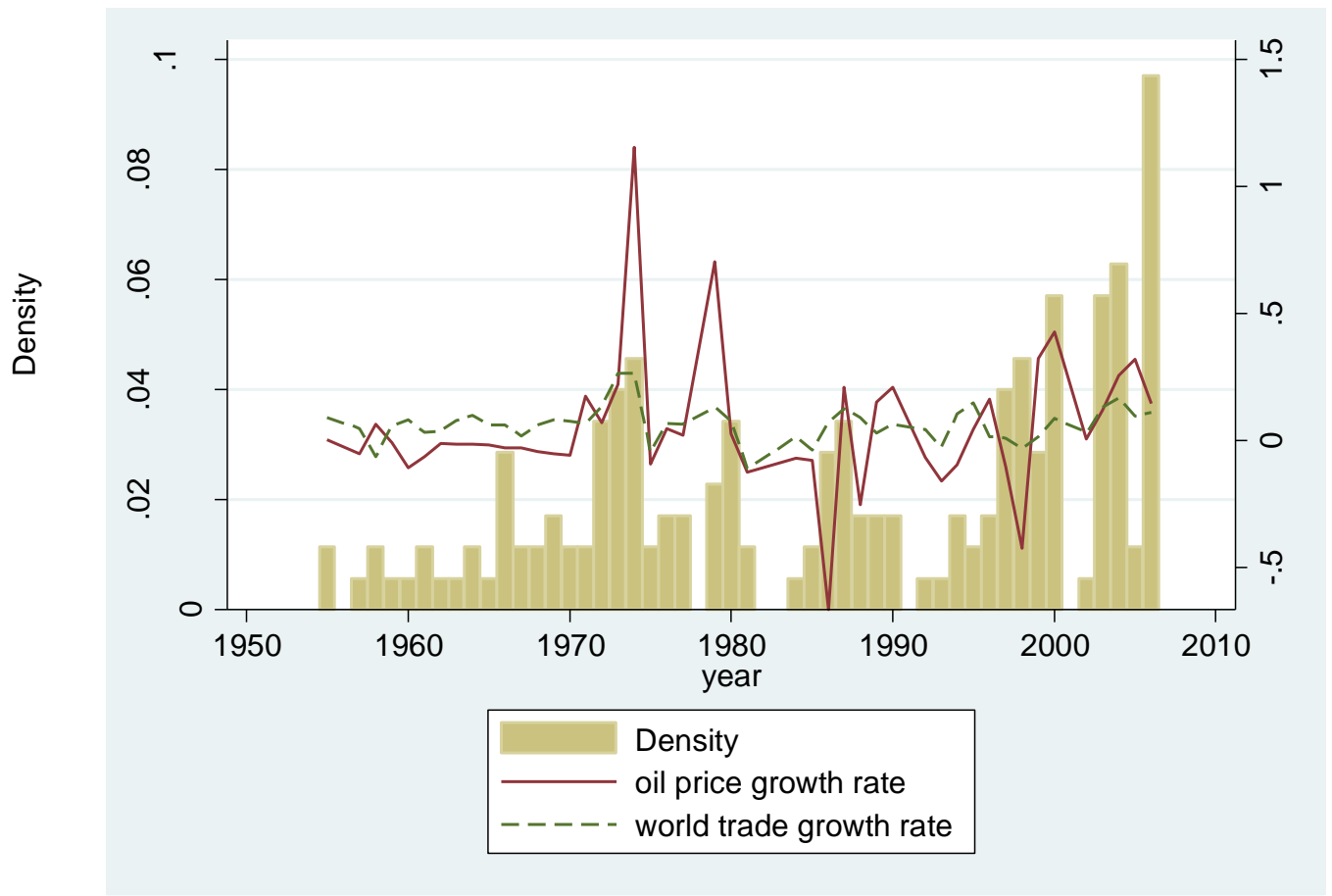

Note: The bars indicate the frequency distribution of years when a TFP slump began. We define slumps by considering successive 5 year periods and isolating episodes where the growth rate of TFP was at least 1.0 per cent lower on average in the second period than the first. A Chow test episode is selected out of the consecutive slumps by employing a Chow test for structural breaks. ). Oil prices are crude oil prices per barrel in 2014 dollars, collected from Statistical Review of World Energy 2015. World trade is world trade in merchandise in current US dollars, collected from WTO and then deflated by the US CPI. Oil countries are not included. 
Figure 6. Years TFP Slumps Started, LIBOR and TED Spread

(A) Countries Whose Per Capita GDP is above $\$ 4,000$ : Consecutive Points

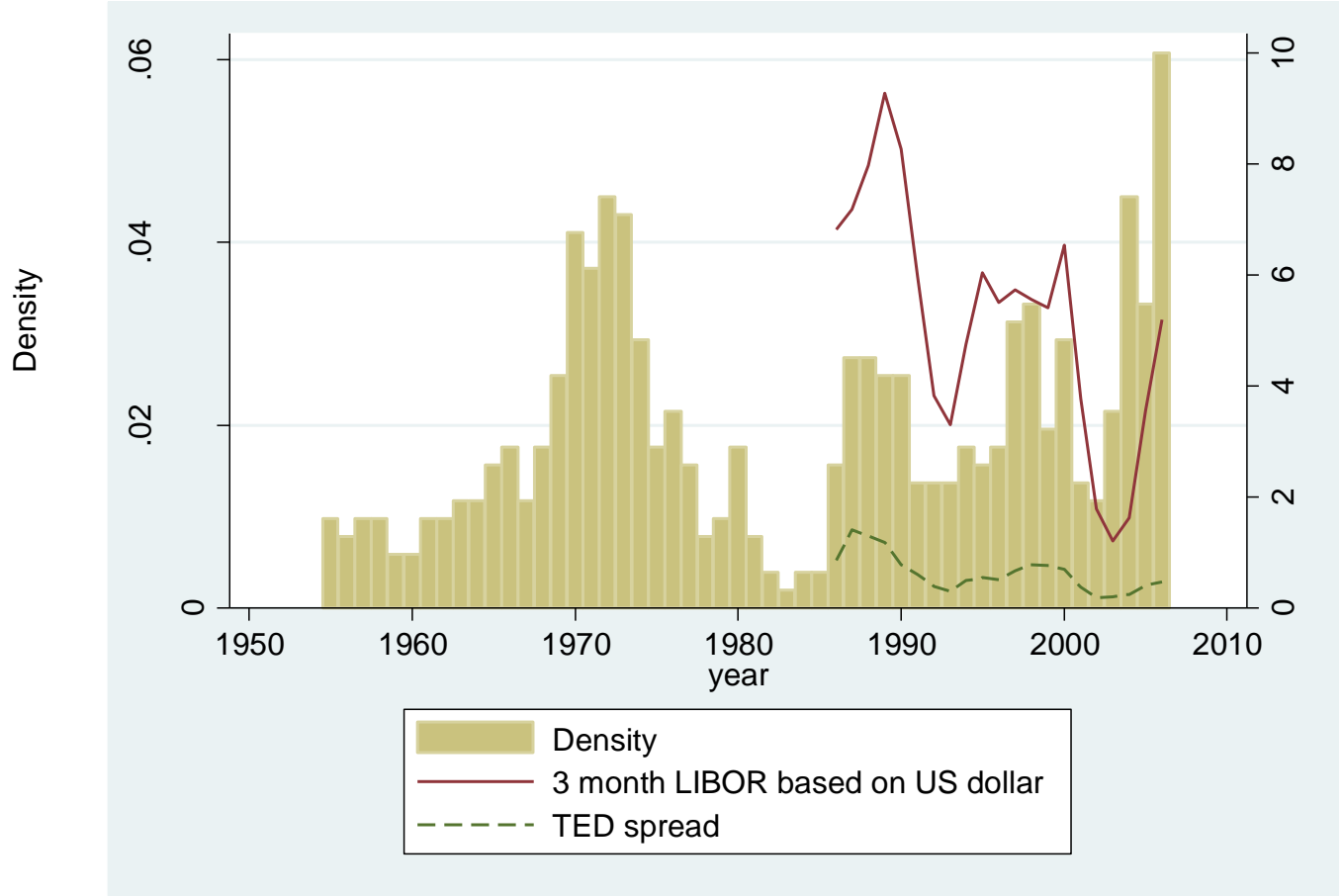

(B) Countries whose per capita GDP is above $\$ 4,000$ : Chow Test Points

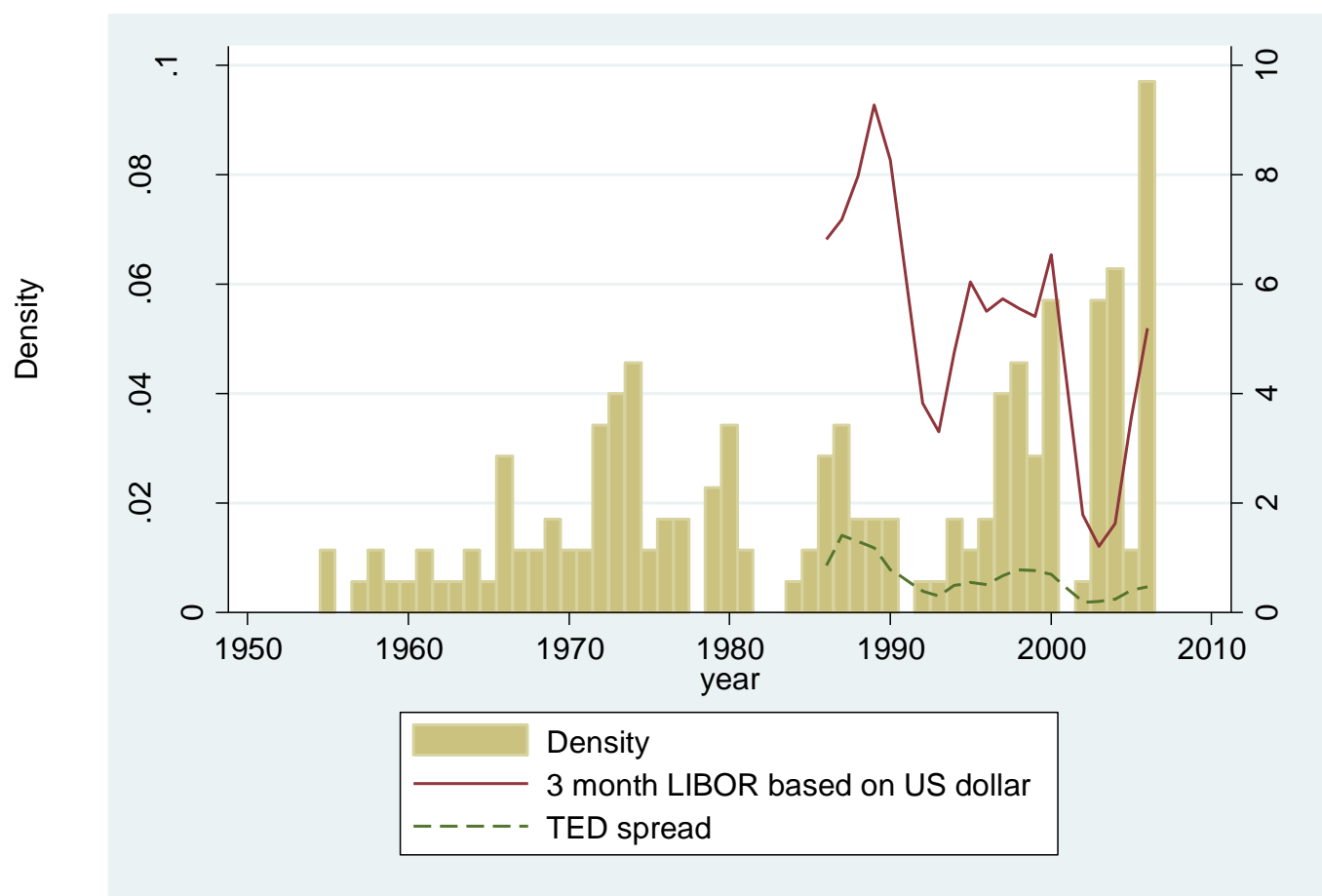

Note: The bars indicate the frequency distribution of years when a TFP slump began. We define slowdowns by considering successive 5 year periods and isolating episodes where the growth rate of TFP was at least 1.0 per cent lower on average in the second period than the first. A Chow test episode is selected out of the consecutive slowdowns by employing a Chow test for structural breaks. Oil countries are not included. 
Table 1. Number of Countries Experiencing Slumps, Accelerations and Recoveries

\begin{tabular}{lccc}
\hline & \multicolumn{3}{c}{ Number of countries experiencing } \\
\hline Definitions & TFP slump & $\begin{array}{c}\text { TFP } \\
\text { acceleration }\end{array}$ & TFP recovery \\
\hline 1\% over successive 5 year periods & 77 & 75 & 66 \\
$1 \%$ over successive 7 year periods & 70 & 70 & 53 \\
$1 \%$ over successive 10 year periods & 59 & 54 & 38 \\
$1.5 \%$ over successive 5 year periods & 74 & 71 & 59 \\
$1.5 \%$ over successive 7 year periods & 68 & 64 & 44 \\
$1.5 \%$ over successive 10 year periods & 52 & 43 & 27 \\
\hline
\end{tabular}

Note: We identify TFP slumps, accelerations and recoveries by considering successive 5,7 and 10 year periods (alternatively) and isolate episodes where the growth rate of TFP was at least 1.0 per cent or 1.5 per cent less (alternatively) on average in the second period than the first. The sample includes only those countries whose per capita GDP is above U.S. 2005 constant $\$ 4,000$. Oil-exporting countries are not included.

Table 2. Oil Shocks and TFP Slumps in Advanced Countries

\begin{tabular}{|c|c|c|}
\hline \multirow{2}{*}{ period } & \# of slumps advanced countries & \# of slumps in advanced countries \\
\hline & \# of advanced countries & \# of all slowdowns \\
\hline $\begin{array}{l}\text { first oil shock } \\
\text { (1968-1975) }\end{array}$ & $18 / 21(=0.86)$ & $19 / 92(=0.21)$ \\
\hline $\begin{array}{l}\text { second oil shock } \\
(1977-1983)\end{array}$ & $6 / 21(=0.29)$ & $7 / 92(=0.08)$ \\
\hline both oil shocks & $18 / 21(=0.86)$ & $26 / 92(=0.28)$ \\
\hline
\end{tabular}

Note: The total number of advanced countries is 21 . Advanced countries include all founding members of the OECD except Turkey, Iceland and Luxembourg. Turkey is excluded due to its low income level. Iceland and Luxembourg are excluded due to data availability. Advanced countries also include Japan, Finland, Australia and New Zealand that joined the OECD during the next 12 years. The first column is the ratio of the number of advanced countries that experienced a slump during the particular period to the total number of advanced countries. The second column is the ratio of the number of slumps experienced by advanced countries during the particular period to the number of slumps experienced by advanced countries during the entire period. The number of slumps is calculated by the slumps identified by the Chow test. 
Table 3. Differences Between Slump Years and Other Years

(A) Countries Whose Per Capita GDP is above \$4,000: Consecutive Points

\begin{tabular}{|c|c|c|c|c|}
\hline & $\begin{array}{l}\text { slowdown } \\
\text { years }\end{array}$ & $\begin{array}{l}\text { other } \\
\text { years }\end{array}$ & difference & $\mathrm{p}$ value \\
\hline per capita GDP & 13,205 & 14,580 & 1376 & 0.00 \\
\hline years of schooling & 7.82 & 8.34 & 0.53 & 0.00 \\
\hline $\begin{array}{l}\text { change in years of schooling } \\
\text { (average from } t-5 \text { to } t \text { ) }\end{array}$ & 0.01 & 0.01 & 0.00 & 0.00 \\
\hline investment rate & 0.25 & 0.23 & -0.02 & 0.00 \\
\hline $\begin{array}{l}\text { manufacturing employment share } \\
\text { change in manufacturing employment }\end{array}$ & 27.99 & 26.39 & -1.60 & 0.00 \\
\hline $\begin{array}{l}\text { share } \\
\text { (average from } t-5 \text { to } t \text { ) }\end{array}$ & -0.12 & -0.30 & -0.18 & 0.00 \\
\hline manufacturing value-added share & 33.79 & 31.66 & -2.13 & 0.00 \\
\hline $\begin{array}{l}\text { (average from } t-5 \text { to } t) \\
\text { hare }\end{array}$ & 0.14 & -0.15 & -0.30 & 0.00 \\
\hline polity2 & 6.03 & 7.89 & 1.86 & 0.00 \\
\hline rule of law & 0.56 & 0.44 & -0.12 & 0.13 \\
\hline real electricity cost & 0.053 & 0.059 & 0.005 & 0.02 \\
\hline real gas cost & 0.014 & 0.019 & 0.005 & 0.00 \\
\hline dependency rate (old) & 14.85 & 15.49 & 0.63 & 0.05 \\
\hline dependency rate (young\&old) & 59.96 & 57.28 & -2.68 & 0.00 \\
\hline openness & 59.38 & 58.47 & -0.91 & 0.62 \\
\hline change in openness (average from t-5 to $t$ ) & 1.57 & 1.25 & -0.32 & 0.00 \\
\hline terms of trade & 106.13 & 104.96 & -1.16 & 0.51 \\
\hline undervaluation & 0.02 & -0.03 & -0.05 & 0.00 \\
\hline inflation & 0.08 & 0.07 & -0.01 & 0.00 \\
\hline inflation variability & 0.48 & 0.52 & 0.04 & 0.02 \\
\hline
\end{tabular}


(B) Countries Whose Per Capita GDP is above $\$ 4,000$ : Chow Test Points

\begin{tabular}{lrrrr}
\hline & $\begin{array}{c}\text { slowdown } \\
\text { years }\end{array}$ & $\begin{array}{r}\text { other } \\
\text { years }\end{array}$ & difference & p value \\
\hline per capita GDP & 13,902 & 13,993 & 91 & 0.86 \\
years of schooling & 8.04 & 8.15 & 0.11 & 0.39 \\
change in years of schooling & 0.01 & 0.01 & 0.00 & 0.11 \\
(average from t-5 to t) & 0.25 & 0.23 & -0.02 & 0.00 \\
investment rate & 28.03 & 26.49 & -1.55 & 0.00 \\
manufacturing employment share & -0.16 & -0.28 & -0.12 & 0.00 \\
change in manufacturing employment share & 33.56 & 32.00 & -1.56 & 0.00 \\
(average from t-5 to t) & 0.09 & -0.15 & -0.24 & 0.00 \\
manufacturing value-added share & 6.45 & 7.37 & 0.92 & 0.00 \\
change in manufacturing value-added share & 0.53 & 0.48 & -0.05 & 0.58 \\
(average from t-5 to t) & 0.051 & 0.060 & 0.009 & 0.00 \\
polity2 & 0.014 & 0.018 & 0.004 & 0.00 \\
rule of law & 15.19 & 15.11 & -0.08 & 0.82 \\
real electricity cost & 58.72 & 58.59 & -0.13 & 0.86 \\
real gas cost & 60.51 & 57.92 & -2.59 & 0.20 \\
dependency rate (old) & 1.52 & 1.22 & -0.30 & 0.01 \\
dependency rate (young\&old) & 105.63 & 105.75 & 0.12 & 0.95 \\
openness & 0.01 & -0.01 & -0.02 & 0.25 \\
change in openness (average from t-5 to t) & 0.08 & 0.07 & -0.01 & 0.00 \\
terms of trade & 0.47 & 0.52 & 0.05 & 0.00 \\
undervaluation & & & & \\
inflation & & & \\
inflation variability & & & \\
\hline
\end{tabular}


(C) Countries Whose Per Capita GDP is above \$10,000: Consecutive Points

\begin{tabular}{lrrrr}
\hline & $\begin{array}{c}\text { slowdown } \\
\text { years }\end{array}$ & other years & difference & p value \\
\hline per capita GDP & 18,569 & 22,114 & 3546 & 0.00 \\
years of schooling & 9.11 & 9.83 & 0.72 & 0.00 \\
change in years of schooling & & 0.01 & 0.00 & 0.00 \\
(average from t-5 to t) & 0.27 & 0.26 & -0.01 & 0.05 \\
investment rate & 29.47 & 27.78 & -1.69 & 0.00 \\
manufacturing employment share & & & & \\
change in manufacturing employment & -0.19 & -0.39 & -0.20 & 0.00 \\
share & & & & \\
(average from t-5 to t) & 33.11 & 30.36 & -2.75 & 0.00 \\
manufacturing value-added share & & & & \\
change in manufacturing value-added & -0.01 & -0.18 & -0.17 & 0.00 \\
share & & & & \\
(average from t-5 to t) & 8.89 & 9.75 & 0.86 & 0.00 \\
polity2 & 0.93 & 1.15 & 0.22 & 0.01 \\
rule of law & 0.05 & 0.06 & 0.01 & 0.01 \\
real electricity cost & 0.01 & 0.02 & 0.00 & 0.00 \\
real gas cost & 18.16 & 19.77 & 1.61 & 0.00 \\
dependency rate (old) & 53.34 & 51.93 & -1.41 & 0.00 \\
dependency rate (young\&old) & 59.36 & 62.63 & 3.27 & 0.18 \\
openness & 1.70 & 1.64 & -0.06 & 0.67 \\
change in openness (average from t-5 to t) & -0.07 & -0.14 & -0.07 & 0.00 \\
terms of trade & 0.06 & 0.05 & -0.02 & 0.00 \\
undervaluation & 0.42 & 0.44 & 0.02 & 0.33 \\
inflation & & & & \\
inflation variability & & & & \\
\hline
\end{tabular}


(D) Countries Whose Per Capita GDP is above $\$ 10,000$ : Chow Test Points

\begin{tabular}{|c|c|c|c|c|}
\hline & $\begin{array}{l}\text { slowdown } \\
\text { years }\end{array}$ & other years & difference & $\mathrm{p}$ value \\
\hline per capita GDP & 18,719 & 21,526 & 2808 & 0.00 \\
\hline \multirow{2}{*}{$\begin{array}{l}\text { years of schooling } \\
\text { change in years of schooling } \\
\text { (average from t- } 5 \text { to } t)\end{array}$} & 9.17 & 9.69 & 0.51 & 0.00 \\
\hline & 0.01 & 0.01 & 0.00 & 0.58 \\
\hline investment rate & 0.26 & 0.26 & 0.00 & 0.56 \\
\hline $\begin{array}{l}\text { manufacturing employment share } \\
\text { change in manufacturing employment }\end{array}$ & 29.39 & 28.01 & -1.38 & 0.00 \\
\hline \multicolumn{5}{|l|}{ (average from $t-5$ to $t$ ) } \\
\hline manufacturing value-added share & 32.89 & 30.76 & -2.13 & 0.00 \\
\hline \multicolumn{5}{|l|}{ (average from $t-5$ to $t$ ) } \\
\hline polity2 & 8.80 & 9.64 & 0.84 & 0.00 \\
\hline rule of law & 0.93 & 1.13 & 0.21 & 0.02 \\
\hline real electricity cost & 0.05 & 0.06 & 0.01 & 0.00 \\
\hline real gas cost & 0.01 & 0.02 & 0.00 & 0.00 \\
\hline dependency rate (old) & 18.21 & 19.42 & 1.20 & 0.00 \\
\hline dependency rate (young\&old) & 53.54 & 52.14 & -1.40 & 0.01 \\
\hline openness & 59.24 & 61.48 & 2.25 & 0.39 \\
\hline change in openness (average from t-5 to $t$ ) & 1.60 & 1.50 & -0.10 & 0.43 \\
\hline terms of trade & 106.24 & 105.22 & -1.02 & 0.72 \\
\hline undervaluation & -0.07 & -0.13 & -0.06 & 0.00 \\
\hline inflation & 0.07 & 0.05 & -0.02 & 0.00 \\
\hline inflation variability & 0.43 & 0.44 & 0.01 & 0.49 \\
\hline \multicolumn{5}{|c|}{$\begin{array}{l}\text { Note: Slump years refer to those years when a TFP slump began }(\mathrm{T}) \text {. We also include one year preceding }(\mathrm{T}-1) \\
\text { and one year following }(\mathrm{T}+1) \text { the beginning year as slump years. We drop all data pertaining to years, } \mathrm{T}+2, \mathrm{~T}+3 \text {, } \\
\mathrm{T}+4 \text { and } \mathrm{T}+5 \text { of the growth slump to contrast more clearly slump years with other years. Real electricity cost } \\
\text { and real gas cost are converted to real by deflating nominal values in the current UK pounds, reported by } \\
\text { international energy price comparison statistics, by the UK CPI. We removed outliers found in openness (greater } \\
\text { than } 200 \% \text { ), inflation (greater than } 50 \% \text { ) and the inflation variability (greater than } 2 \text { ). The last column reports } \\
\text { the p-value for the null hypothesis of no difference for each variable between slowdown years and other years. } \\
\text { The sample includes only those countries whose per capita GDP is above U.S. } 2005 \text { constant } \$ 4,000 \text {. Oil- } \\
\text { exporting countries are not included. }\end{array}$} \\
\hline
\end{tabular}


Table 4. Determinants of TFP Slumps for Countries with Per Capita GDP above \$4,000 (Logit, Consecutive Points)

\begin{tabular}{|c|c|c|c|c|c|c|c|c|c|c|c|c|c|c|c|}
\hline VARIABLES & (1) & (2) & (3) & (4) & (5) & (6) & (7) & (8) & (9) & (10) & (11) & (12) & (13) & (14) & (15) \\
\hline \multirow{2}{*}{ per capita GDP } & 1.847 & -4.336 & -5.830 & $-15.715^{*}$ & -5.466 & 4.969 & 12.806 & -1.219 & 1.228 & -1.317 & -4.085 & -3.837 & -1.264 & -1.065 & 15.058 \\
\hline & {$[4.406]$} & [3.983] & {$[4.170]$} & {$[9.241]$} & [10.451] & {$[4.279]$} & [21.944] & {$[4.225]$} & [4.687] & {$[3.902]$} & [3.983] & [4.357] & {$[3.901]$} & [3.930] & {$[17.693]$} \\
\hline \multirow{2}{*}{ per capita GDP square } & 0.004 & 0.330 & $0.405^{*}$ & $1.055^{* *}$ & 0.561 & -0.147 & -0.256 & 0.173 & 0.043 & 0.172 & 0.315 & 0.333 & 0.169 & 0.162 & -0.563 \\
\hline & {$[0.234]$} & {$[0.211]$} & {$[0.220]$} & {$[0.483]$} & {$[0.547]$} & {$[0.225]$} & [1.166] & {$[0.225]$} & {$[0.250]$} & {$[0.207]$} & {$[0.211]$} & {$[0.234]$} & {$[0.207]$} & {$[0.208]$} & {$[0.908]$} \\
\hline \multirow{2}{*}{ years of schooling } & -1.040 & & & & & & & & & & & & & & $-11.659^{* * *}$ \\
\hline & {$[0.665]$} & & & & & & & & & & & & & & [3.869] \\
\hline \multirow{2}{*}{ change in years of schooling (from t- 5 to $t$ ) } & & -11.745 & & & & & & & & & & & & & \\
\hline & & {$[8.055]$} & & & & & & & & & & & & & \\
\hline \multirow{2}{*}{ investment rate } & & & $4.840 * * *$ & & & & & & & & & & & & $14.000 * * *$ \\
\hline & & & {$[1.616]$} & & & & & & & & & & & & [4.614] \\
\hline \multirow{2}{*}{ manufacturing employment share } & & & & 0.074 & & & & & & & & & & & 0.036 \\
\hline & & & & {$[0.050]$} & & & & & & & & & & & {$[0.098]$} \\
\hline \multirow{2}{*}{$\begin{array}{l}\text { change in manufacturing employment share } \\
\text { (from } t-5 \text { to } t \text { ) }\end{array}$} & & & & & $1.124^{* * *}$ & & & & & & & & & & $0.906 * * *$ \\
\hline & & & & & {$[0.245]$} & & & & & & & & & & {$[0.341]$} \\
\hline \multirow[t]{2}{*}{ polity2 } & & & & & & $-0.082 * * *$ & & & & & & & & & $-0.212^{* * *}$ \\
\hline & & & & & & [0.023] & & & & & & & & & [0.079] \\
\hline \multirow[t]{2}{*}{ rule of law } & & & & & & & 1.091 & & & & & & & & \\
\hline & & & & & & & [1.269] & & & & & & & & \\
\hline \multirow[t]{2}{*}{ dependency rate (old) } & & & & & & & & 0.034 & & & & & & & $-0.204 *$ \\
\hline & & & & & & & & [0.042] & & & & & & & {$[0.120]$} \\
\hline \multirow{2}{*}{ dependency rate (young\&old) } & & & & & & & & & 0.018 & & & & & & 0.046 \\
\hline & & & & & & & & & [0.013] & & & & & & {$[0.058]$} \\
\hline \multirow{2}{*}{ openness } & & & & & & & & & & 0.001 & & & & & $0.033^{*}$ \\
\hline & & & & & & & & & & [0.005] & & & & & [0.018] \\
\hline \multirow{2}{*}{ change in openness (from $t-5$ to $t$ ) } & & & & & & & & & & & 0.036 & & & & 0.042 \\
\hline & & & & & & & & & & & [0.038] & & & & {$[0.111]$} \\
\hline \multirow{2}{*}{ undervaluation } & & & & & & & & & & & & $0.891^{*}$ & & & -1.108 \\
\hline & & & & & & & & & & & & {$[0.472]$} & & & [1.291] \\
\hline \multirow[t]{2}{*}{ Inflation } & & & & & & & & & & & & & -1.068 & & -1.287 \\
\hline & & & & & & & & & & & & & {$[1.122]$} & & [3.327] \\
\hline
\end{tabular}




$1,484 \quad 1,555$

723

573

1,535

284

1,394

1,394

1,555

1,484

1,394

1,555

[0.247]

Note: We report logit regression results with year and country fixed effects included. The dependent variable is a dummy variable that takes the value of 1 for the three years centered on the year when a TFP slump begins. We define slowdowns by considering successive 5 year periods and isolating episodes where the growth rate of TFP was at least 1.0 per cent lower on average in the second period than the first. We use the entire string of consecutive years as TFP slumps. The sample includes only those countries whose per capita GDP is above U.S. 2005 constant $\$ 4,000$. Oil countries are not included. *Statistically significant at the 10 percent level. **Statistically significant at the 5 percent level. $* * *$ Statistically significant at the 1 percent level. 
Table 5. Determinants of TFP Slumps for Countries with Per Capita GDP above \$10,000 (Logit, Consecutive Points)

\begin{tabular}{|c|c|c|c|c|c|c|c|c|c|c|c|c|c|c|c|}
\hline VARIABLES & (1) & (2) & (3) & (4) & (5) & (6) & (7) & (8) & (9) & (10) & (11) & (12) & (13) & (14) & (15) \\
\hline \multirow{2}{*}{ per capita GDP } & -1.644 & -18.559 & -24.430 & -25.050 & -9.628 & -2.652 & $110.550^{* * *}$ & -23.635 & -26.760 & -18.976 & -22.967 & -26.252 & -27.563 & -19.437 & -20.742 \\
\hline & {$[17.061]$} & {$[16.566]$} & [16.472] & [22.243] & [23.505] & [17.118] & [38.501] & [17.219] & [17.315] & [16.593] & {$[16.488]$} & {$[17.311]$} & [17.367] & [16.303] & {$[27.417]$} \\
\hline \multirow{2}{*}{ per capita GDP square } & 0.314 & 1.157 & $1.461^{*}$ & 1.438 & 0.752 & 0.330 & $-5.225 * * *$ & 1.418 & $1.576^{*}$ & 1.179 & 1.376 & $1.549^{*}$ & $1.615^{*}$ & 1.201 & 1.145 \\
\hline & {$[0.864]$} & {$[0.841]$} & {$[0.838]$} & [1.126] & [1.187] & {$[0.870]$} & {$[1.886]$} & {$[0.876]$} & {$[0.883]$} & {$[0.842]$} & {$[0.838]$} & {$[0.878]$} & {$[0.884]$} & [0.829] & {$[1.384]$} \\
\hline \multirow{2}{*}{ years of schooling } & $-4.947 * * *$ & & & & & & & & & & & & & & $-13.578 * * *$ \\
\hline & {$[1.662]$} & & & & & & & & & & & & & & [3.960] \\
\hline \multirow{2}{*}{ change in years of schooling (from $t-5$ to $t$ ) } & & $-47.016^{* *}$ & & & & & & & & & & & & & \\
\hline & & {$[18.271]$} & & & & & & & & & & & & & \\
\hline \multirow[t]{2}{*}{ investment rate } & & & $4.748^{*}$ & & & & & & & & & & & & $13.576^{* *}$ \\
\hline & & & {$[2.754]$} & & & & & & & & & & & & {$[5.425]$} \\
\hline \multirow{2}{*}{ manufacturing employment share } & & & & $0.199 * *$ & & & & & & & & & & & 0.182 \\
\hline & & & & {$[0.091]$} & & & & & & & & & & & {$[0.117]$} \\
\hline \multirow{2}{*}{$\begin{array}{l}\text { change in manufacturing employment share } \\
\text { (from } t-5 \text { to } t \text { ) }\end{array}$} & & & & & $1.261^{* * *}$ & & & & & & & & & & \\
\hline & & & & & {$[0.360]$} & & & & & & & & & & \\
\hline \multirow[t]{2}{*}{ polity2 } & & & & & & $-0.224 * *$ & & & & & & & & & -0.332 \\
\hline & & & & & & {$[0.102]$} & & & & & & & & & {$[0.209]$} \\
\hline \multirow[t]{2}{*}{ rule of law } & & & & & & & 1.910 & & & & & & & & \\
\hline & & & & & & & [1.917] & & & & & & & & \\
\hline \multirow[t]{2}{*}{ dependency rate (old) } & & & & & & & & -0.047 & & & & & & & \\
\hline & & & & & & & & {$[0.064]$} & & & & & & & \\
\hline \multirow[t]{2}{*}{ dependency rate (young\&old) } & & & & & & & & & -0.003 & & & & & & -0.018 \\
\hline & & & & & & & & & {$[0.025]$} & & & & & & {$[0.054]$} \\
\hline \multirow{2}{*}{ openness } & & & & & & & & & & -0.002 & & & & & 0.027 \\
\hline & & & & & & & & & & {$[0.010]$} & & & & & {$[0.025]$} \\
\hline \multirow{2}{*}{ change in openness (from $t-5$ to $t$ ) } & & & & & & & & & & & 0.014 & & & & -0.014 \\
\hline & & & & & & & & & & & {$[0.080]$} & & & & {$[0.148]$} \\
\hline \multirow{2}{*}{ undervaluation } & & & & & & & & & & & & 0.003 & & & -0.566 \\
\hline & & & & & & & & & & & & {$[0.900]$} & & & {$[1.577]$} \\
\hline \multirow[t]{2}{*}{ inflation } & & & & & & & & & & & & & -4.522 & & -0.383 \\
\hline & & & & & & & & & & & & & {$[3.023]$} & & {$[4.616]$} \\
\hline
\end{tabular}


Note: We report logit regression results with year and country fixed effects included. The dependent variable is a dummy variable that takes the value of 1 for the three years centered on the year when a TFP slump begins. We define slumps by considering successive 5 year periods and isolating episodes where the growth rate of TFP was at least 1.0 per cent lower on average in the second period than the first. We use the entire string of consecutive years as TFP slumps. The sample includes only those countries

whose per capita GDP is above U.S. 2005 constant $\$ 10,000$. Oil countries are not included. *Statistically significant at the 10 percent level. **Statistically significant at the 5 percent level. $* * *$ Statistically significant at the 1 percent level. 
Table 6. The Impact of Openness on TFP Slumps when Openness is not High

\begin{tabular}{|c|c|c|c|c|c|c|c|c|}
\hline VARIABLES & $\begin{array}{l}\text { (1) Probit, } \\
\text { Per Capita } \\
\text { GDP above } \\
\$ 4,000\end{array}$ & $\begin{array}{c}\text { (2 Probit, Per } \\
\text { Capita GDP } \\
\text { above } \\
\$ 4,000)\end{array}$ & $\begin{array}{l}\text { (3) Probit, } \\
\text { Per Capita } \\
\text { GDP above } \\
\$ 10,000\end{array}$ & $\begin{array}{l}\text { (4) Probit, } \\
\text { Per Capita } \\
\text { GDP above } \\
\$ 10,000\end{array}$ & $\begin{array}{l}\text { (5) Logit, } \\
\text { Per Capita } \\
\text { GDP above } \\
\$ 4,000\end{array}$ & $\begin{array}{l}\text { (6) Logit, } \\
\text { Per Capita } \\
\text { GDP above } \\
\$ 4,000\end{array}$ & $\begin{array}{l}\text { (7) Logit, } \\
\text { Per Capita } \\
\text { GDP above } \\
\$ 10,000\end{array}$ & $\begin{array}{l}\text { (8) Logit, } \\
\text { Per Capita } \\
\text { GDP above } \\
\$ 10,000\end{array}$ \\
\hline \multirow{2}{*}{ per capita GDP } & 2.223 & 10.324 & -11.731 & -20.044 & -1.601 & 27.252 & -32.963 & -20.813 \\
\hline & [3.596] & [7.105] & [9.174] & [14.536] & {$[4.760]$} & [22.372] & [21.567] & {$[30.420]$} \\
\hline \multirow{2}{*}{ per capita GDP square } & -0.123 & -0.548 & 0.562 & 0.972 & 0.201 & -1.147 & $1.900 *$ & 1.151 \\
\hline & [0.194] & [0.366] & [0.467] & [0.713] & {$[0.251]$} & [1.141] & [1.110] & [1.546] \\
\hline \multirow{2}{*}{ years of schooling } & & 0.213 & & -1.400 & & $-8.265^{*}$ & & $-12.842 * * *$ \\
\hline & & [0.533] & & [0.959] & & [4.409] & & [4.277] \\
\hline \multirow{2}{*}{ investment rate } & & 3.234 & & 1.935 & & $16.362^{* * *}$ & & 9.105 \\
\hline & & [2.199] & & [3.237] & & {$[5.950]$} & & [6.302] \\
\hline \multirow{2}{*}{ manufacturing employment share } & & 0.011 & & $-0.076 * *$ & & -0.044 & & 0.189 \\
\hline & & {$[0.026]$} & & {$[0.036]$} & & [0.139] & & [0.133] \\
\hline \multirow{2}{*}{$\begin{array}{l}\text { change in manufacturing employment share } \\
\text { (from } t-5 \text { to } t \text { ) }\end{array}$} & & $0.384 * *$ & & $0.780 * *$ & & $1.162 * * *$ & & \\
\hline & & {$[0.191]$} & & {$[0.347]$} & & {$[0.443]$} & & \\
\hline \multirow{2}{*}{ polity2 } & & -0.017 & & $-0.261^{*}$ & & -0.096 & & -0.288 \\
\hline & & [0.033] & & {$[0.154]$} & & {$[0.092]$} & & {$[0.185]$} \\
\hline \multirow{2}{*}{ dependency rate (old) } & & -0.003 & & 0.032 & & $-0.305^{* *}$ & & \\
\hline & & {$[0.021]$} & & [0.031] & & {$[0.131]$} & & \\
\hline \multirow{2}{*}{ dependency rate (young\&old) } & & 0.008 & & -0.027 & & $0.264 * * *$ & & -0.009 \\
\hline & & {$[0.021]$} & & {$[0.028]$} & & {$[0.102]$} & & {$[0.065]$} \\
\hline \multirow{2}{*}{ openness } & $-0.009 * *$ & -0.003 & $-0.010^{*}$ & -0.003 & -0.013 & -0.046 & -0.039 & 0.019 \\
\hline & {$[0.004]$} & {$[0.007]$} & {$[0.006]$} & [0.007] & {$[0.012]$} & [0.049] & {$[0.025]$} & [0.038] \\
\hline \multirow{2}{*}{ change in openness (from $t-5$ to $t$ ) } & & -0.094 & & -0.141 & & 0.113 & & 0.015 \\
\hline & & {$[0.078]$} & & [0.124] & & [0.279] & & [0.182] \\
\hline \multirow{2}{*}{ undervaluation } & & -0.235 & & -0.897 & & -1.126 & & -0.898 \\
\hline & & [0.477] & & [0.637] & & [1.574] & & [1.672] \\
\hline \multirow{2}{*}{ inflation } & & 0.606 & & 1.716 & & -4.031 & & 1.138 \\
\hline & & [1.440] & & {$[2.015]$} & & [3.622] & & [4.660] \\
\hline inflation variability & & 0.369 & & $0.553^{*}$ & & 0.812 & & 0.494 \\
\hline
\end{tabular}




\begin{tabular}{|c|c|c|c|c|c|c|c|c|}
\hline & & [0.239] & & [0.286] & & [0.646] & & [0.742] \\
\hline Observations & 1,228 & 459 & 620 & 321 & 1,227 & 389 & 641 & 389 \\
\hline Pseudo R-squared & 0.145 & 0.0990 & 0.184 & 0.194 & 0.199 & 0.218 & 0.291 & 0.295 \\
\hline
\end{tabular}

Note: We report probit (column 1-4) regression with year fixed effects and logit (columns 5-7) regression results with year and country fixed effects included. We removed observations if openness is above 80. This reduces the number of observations for openness from 1,604 to 1,263 (about 80\%). The dependent variable is a dummy variable that takes the value of 1 for the three years centered on the year when a TFP slump begins. We define slowdowns by considering successive 5 year periods and isolating episodes where the growth rate of TFP was at least 1.0 per cent lower on average in the second period than the first. We use the entire string of consecutive years as TFP slumps. Oil countries are not included. ${ }^{*}$ Statistically significant at the 10 percent level. ${ }^{* *}$ Statistically significant at the 5 percent level. $* * *$ Statistically significant at the 1 percent level. 
Table 7. The Impact of Inflation and Inflation Variability on TFP Slumps when Inflation Variability is not High

\begin{tabular}{|c|c|c|c|c|c|c|c|c|}
\hline VARIABLES & $\begin{array}{l}\text { (1) Probit, } \\
\text { Per Capita } \\
\text { GDP above } \\
\$ 4,000\end{array}$ & $\begin{array}{c}\text { (2) Probit, } \\
\text { Per Capita } \\
\text { GDP above } \\
\$ 4,000\end{array}$ & $\begin{array}{c}\text { (3) Probit, } \\
\text { Per Capita } \\
\text { GDP above } \\
\$ 10,000\end{array}$ & $\begin{array}{l}\text { (4) Probit, } \\
\text { Per Capita } \\
\text { GDP above } \\
\$ 10,000\end{array}$ & $\begin{array}{c}\text { (5) Logit, } \\
\text { Per Capita } \\
\text { GDP above } \\
\$ 4,000\end{array}$ & $\begin{array}{c}\text { (6) Logit, } \\
\text { Per Capita } \\
\text { GDP above } \\
\$ 4,000\end{array}$ & $\begin{array}{l}\text { (7) Logit, } \\
\text { Per Capita } \\
\text { GDP above } \\
\$ 10,000\end{array}$ & $\begin{array}{c}\text { (8) Logit, } \\
\text { Per Capita } \\
\text { GDP above } \\
\$ 10,000\end{array}$ \\
\hline \multirow{2}{*}{ per capita GDP } & 5.332 & $12.552 *$ & -7.841 & 2.921 & -3.575 & 44.383 & $-33.206 *$ & -20.742 \\
\hline & [3.915] & {$[6.846]$} & {$[10.692]$} & [21.132] & [5.939] & [28.789] & [19.125] & [27.417] \\
\hline \multirow{2}{*}{ per capita GDP square } & -0.291 & $-0.633^{*}$ & 0.366 & -0.163 & 0.290 & -2.071 & $1.846^{*}$ & 1.145 \\
\hline & {$[0.210]$} & [0.355] & [0.543] & [1.050] & [0.314] & [1.464] & {$[0.976]$} & [1.384] \\
\hline \multirow{2}{*}{ years of schooling } & & -0.485 & & -0.030 & & $-14.075 * *$ & & $-13.578 * * *$ \\
\hline & & [0.511] & & {$[0.786]$} & & [5.637] & & [3.960] \\
\hline \multirow{2}{*}{ investment rate } & & $3.102^{*}$ & & 1.830 & & $11.721^{*}$ & & $13.576^{* *}$ \\
\hline & & {$[1.600]$} & & {$[2.211]$} & & {$[6.575]$} & & {$[5.425]$} \\
\hline \multirow{2}{*}{ manufacturing employment share } & & -0.013 & & -0.019 & & 0.032 & & 0.182 \\
\hline & & {$[0.025]$} & & {$[0.036]$} & & {$[0.151]$} & & [0.117] \\
\hline \multirow{2}{*}{$\begin{array}{l}\text { change in manufacturing employment share } \\
\text { (from } t-5 \text { to } t \text { ) }\end{array}$} & & $0.792 * * *$ & & $1.086 * * *$ & & $1.885^{* * *}$ & & \\
\hline & & [0.233] & & [0.287] & & {$[0.574]$} & & \\
\hline \multirow{2}{*}{ polity2 } & & $-0.062 *$ & & -0.118 & & $-0.306 * *$ & & -0.332 \\
\hline & & {$[0.038]$} & & {$[0.072]$} & & [0.120] & & [0.209] \\
\hline \multirow{2}{*}{ dependency rate (old) } & & -0.017 & & 0.005 & & $-0.852 * * *$ & & \\
\hline & & [0.023] & & [0.032] & & [0.222] & & \\
\hline \multirow{2}{*}{ dependency rate (young\&old) } & & -0.010 & & -0.022 & & $0.150 *$ & & -0.018 \\
\hline & & [0.017] & & {$[0.027]$} & & [0.084] & & {$[0.054]$} \\
\hline \multirow{2}{*}{ openness } & & 0.000 & & 0.002 & & 0.005 & & 0.027 \\
\hline & & [0.004] & & {$[0.005]$} & & [0.029] & & {$[0.025]$} \\
\hline \multirow{2}{*}{ change in openness (from $t-5$ to $t$ ) } & & 0.003 & & -0.114 & & 0.092 & & -0.014 \\
\hline & & {$[0.056]$} & & [0.083] & & [0.188] & & [0.148] \\
\hline \multirow{2}{*}{ undervaluation } & & 0.179 & & -0.444 & & -2.301 & & -0.566 \\
\hline & & {$[0.460]$} & & {$[0.866]$} & & {$[2.230]$} & & [1.577] \\
\hline \multirow{2}{*}{ inflation } & & 0.810 & & $5.099 *$ & & -4.012 & & -0.383 \\
\hline & & [1.930] & & [3.079] & & [6.542] & & [4.616] \\
\hline inflation variability & $1.444^{* *}$ & $2.254^{* * *}$ & $1.661 * * *$ & $3.037 * * *$ & $1.838^{* *}$ & $6.881 * * *$ & 1.699 & 0.571 \\
\hline
\end{tabular}




\begin{tabular}{|c|c|c|c|c|c|c|c|c|}
\hline & [0.583] & [0.745] & [0.569] & {$[0.902]$} & [0.898] & [1.896] & [1.168] & [0.717] \\
\hline Observations & 936 & 441 & 550 & 323 & 915 & 351 & 579 & 468 \\
\hline Pseudo R-squared & 0.146 & 0.193 & 0.184 & 0.225 & 0.225 & 0.375 & 0.329 & 0.327 \\
\hline
\end{tabular}

Note: We report probit (column 1-4) regression with year fixed effects and logit (columns 5-7) regression results with year and country fixed effects included. We removed observations if inflation variability is above .5. This reduces the number of observations for inflation variability from 1,923 to 1,118 (about $60 \%$ ). The dependent variable is a dummy variable that takes the value of 1 for the three years centered on the year when a TFP slump begins. We define slumps by considering successive 5 year periods and isolating episodes where the growth rate of TFP was at least 1.0 per cent lower on average in the second period than the first. We use the entire string of consecutive years as TFP slumps. Oil countries are not included. *Statistically significant at the 10 percent level. **Statistically significant at the 5 percent level. ***Statistically significant at the 1 percent level. 
Table 8. The Impact of Global Factors on TFP Slumps (Logit, Consecutive Points)

\begin{tabular}{|c|c|c|c|c|c|c|c|c|c|c|}
\hline \multirow[b]{2}{*}{ VARIABLES } & \multicolumn{5}{|c|}{ countries with per capita gdp above $\$ 4000$} & \multicolumn{5}{|c|}{ countries with per capita gdp above $\$ 10000$} \\
\hline & (1) & $(2)$ & $(3)$ & (4) & $(5)$ & (6) & (7) & (8) & (9) & $(10)$ \\
\hline \multirow{2}{*}{ per capita GDP } & 2.641 & 14.090 & 10.955 & 14.981 & 12.857 & $-23.738^{* *}$ & 18.241 & 25.553 & 17.964 & 26.655 \\
\hline & {$[3.441]$} & [16.609] & [17.233] & {$[16.601]$} & [17.088] & [11.690] & [32.523] & [34.940] & [32.428] & [34.523] \\
\hline \multirow{2}{*}{ per capita GDP square } & -0.121 & -0.469 & -0.300 & -0.510 & -0.394 & $1.195^{* *}$ & -0.665 & -0.991 & -0.647 & -1.040 \\
\hline & {$[0.182]$} & [0.843] & [0.877] & [0.842] & [0.869] & [0.593] & [1.599] & [1.719] & [1.594] & [1.698] \\
\hline \multirow{2}{*}{ years of schooling } & & $-12.439 * * *$ & $-12.163^{* * *}$ & $-12.187^{* * *}$ & $-12.162^{* * *}$ & & $-17.849 * * *$ & $-17.895 * * *$ & $-17.385 * * *$ & $-17.676 * * *$ \\
\hline & & {$[3.540]$} & {$[3.528]$} & [3.539] & {$[3.528]$} & & [4.451] & [4.482] & {$[4.423]$} & [4.459] \\
\hline \multirow{2}{*}{ investment rate } & & $16.921^{* * *}$ & $14.984^{* * *}$ & $16.759 * * *$ & $15.108^{* * *}$ & & $17.606^{* * *}$ & $13.109 * *$ & $16.041^{* * *}$ & $12.286^{* *}$ \\
\hline & & {$[4.377]$} & {$[4.454]$} & {$[4.366]$} & {$[4.443]$} & & [6.108] & {$[6.280]$} & {$[6.036]$} & [6.136] \\
\hline \multirow{2}{*}{ manufacturing employment share } & & -0.065 & -0.050 & -0.072 & -0.056 & & $-0.283^{* *}$ & $-0.273^{* *}$ & $-0.351^{* *}$ & $-0.342 * *$ \\
\hline & & {$[0.083]$} & {$[0.083]$} & {$[0.083]$} & {$[0.084]$} & & [0.139] & [0.139] & {$[0.142]$} & {$[0.144]$} \\
\hline \multirow{2}{*}{$\begin{array}{l}\text { change in manufacturing employment share } \\
\text { (from } t-5 \text { to } t \text { ) }\end{array}$} & & $1.033^{* * *}$ & $1.095^{* * *}$ & $1.061^{* * *}$ & $1.122^{* * *}$ & & $1.553^{* * *}$ & $1.945^{* * *}$ & $1.782^{* * *}$ & $2.202^{* * *}$ \\
\hline & & {$[0.323]$} & {$[0.328]$} & {$[0.324]$} & {$[0.331]$} & & [0.502] & {$[0.541]$} & {$[0.521]$} & {$[0.566]$} \\
\hline \multirow{2}{*}{ polity2 } & & $-0.226^{* * *}$ & $-0.212^{* * *}$ & $-0.222 * * *$ & $-0.210^{* *}$ & & $-1.522^{* *}$ & $-1.797 * * *$ & $-1.644^{* *}$ & $-1.937^{* * *}$ \\
\hline & & {$[0.080]$} & {$[0.082]$} & {$[0.080]$} & {$[0.082]$} & & {$[0.643]$} & {$[0.677]$} & {$[0.650]$} & {$[0.687]$} \\
\hline \multirow{2}{*}{ dependency rate (old) } & & -0.187 & -0.172 & -0.176 & -0.168 & & -0.107 & -0.113 & -0.047 & -0.066 \\
\hline & & {$[0.117]$} & {$[0.115]$} & [0.117] & {$[0.115]$} & & {$[0.128]$} & {$[0.128]$} & [0.129] & {$[0.130]$} \\
\hline \multirow{2}{*}{ dependency rate (young\&old) } & & 0.028 & 0.025 & 0.029 & 0.028 & & 0.016 & 0.014 & -0.001 & 0.001 \\
\hline & & {$[0.056]$} & {$[0.057]$} & {$[0.056]$} & {$[0.057]$} & & {$[0.083]$} & {$[0.085]$} & {$[0.083]$} & {$[0.085]$} \\
\hline \multirow{2}{*}{ openness } & & $0.043^{* * *}$ & $0.040^{* *}$ & $0.043^{* * *}$ & $0.040^{* *}$ & & $0.058^{* *}$ & $0.047^{*}$ & $0.060^{* *}$ & $0.048^{*}$ \\
\hline & & {$[0.016]$} & {$[0.017]$} & {$[0.016]$} & {$[0.016]$} & & {$[0.025]$} & {$[0.026]$} & {$[0.025]$} & {$[0.026]$} \\
\hline \multirow{2}{*}{ change in openness (from $t-5$ to $t$ ) } & & -0.018 & 0.018 & -0.020 & 0.022 & & -0.157 & -0.095 & -0.187 & -0.108 \\
\hline & & {$[0.094]$} & {$[0.097]$} & [0.093] & {$[0.097]$} & & {$[0.156]$} & {$[0.162]$} & {$[0.153]$} & {$[0.160]$} \\
\hline \multirow{2}{*}{ undervaluation } & & 0.253 & -0.026 & 0.087 & -0.146 & & 1.405 & 1.045 & 0.606 & 0.325 \\
\hline & & [1.119] & [1.131] & [1.134] & [1.145] & & [1.625] & [1.681] & {$[1.675]$} & {$[1.730]$} \\
\hline \multirow{2}{*}{ inflation } & & -2.040 & -2.735 & -1.539 & -2.050 & & -0.719 & -2.355 & 1.272 & -0.277 \\
\hline & & [2.881] & [2.992] & {$[2.900]$} & {$[2.996]$} & & {$[4.924]$} & {$[4.900]$} & [4.901] & {$[4.874]$} \\
\hline \multirow[t]{2}{*}{ inflation variability } & & 0.667 & 0.651 & 0.684 & 0.691 & & 0.582 & 0.717 & 0.507 & 0.717 \\
\hline & & {$[0.560]$} & {$[0.557]$} & {$[0.558]$} & {$[0.555]$} & & {$[0.772]$} & {$[0.777]$} & {$[0.771]$} & {$[0.778]$} \\
\hline oil price growth rate & $0.696 * * *$ & 0.443 & -0.201 & 0.396 & -0.158 & $1.008 * * *$ & 0.459 & -0.443 & 0.163 & -0.681 \\
\hline
\end{tabular}




\begin{tabular}{|c|c|c|c|c|c|c|c|c|c|}
\hline \multirow[t]{7}{*}{ [0.213] } & [0.467] & [0.528] & [0.464] & [0.517] & {$[0.287]$} & [0.574] & [0.667] & [0.574] & [0.667] \\
\hline & 0.061 & 0.103 & & & & 0.098 & 0.160 & & \\
\hline & {$[0.078]$} & [0.081] & & & & [0.101] & {$[0.106]$} & & \\
\hline & & $5.303^{* * *}$ & & $4.922^{* *}$ & & & $7.203^{* * *}$ & & $7.056^{* * *}$ \\
\hline & & {$[2.040]$} & & {$[2.003]$} & & & {$[2.665]$} & & [2.666] \\
\hline & & & 0.641 & 0.707 & & & & $1.739^{* *}$ & $1.898^{* * *}$ \\
\hline & & & [0.525] & [0.530] & & & & [0.693] & {$[0.704]$} \\
\hline 1,555 & 554 & 554 & 554 & 554 & 824 & 379 & 379 & 379 & 379 \\
\hline 0.0119 & 0.232 & 0.245 & 0.233 & 0.245 & 0.0216 & 0.239 & 0.261 & 0.255 & 0.276 \\
\hline
\end{tabular}

world trade growth rate

$0.0119 \quad 0.232$

$0.233-0.245$

0.0216

Note: We report logit regression results with year and country fixed effects included. The dependent variable is a dummy variable that takes the value of 1 for the three years
centered on the year when a TFP slump begins. We define slumps by considering successive 5 year periods and isolating episodes where the growth rate of TFP was at least

1.0 per cent lower on average in the second period than the first. We use the entire string of consecutive years as TFP slumps. The sample includes only those countries

whose per capita GDP is above U.S. 2005 constant $\$ 4,000$ (columns 1-5) and only those with per capita GDP is above U.S. 2005 constant \$10,000 (columns 6-10). Real oil

price is crude oil price per barrel in 2014 dollars, collected from Statistical Review of World Energy 2015. Real world trade is world trade in merchandise in current US

dollars, collected from WTO and then deflated by the US CPI. The data for LIBOR and TED spread start from 1986. Oil countries are not included. *Statistically significant

at the 10 percent level. **Statistically significant at the 5 percent level. ***Statistically significant at the 1 percent level. 


\section{Appendix}

In this appendix we first detail the definitions and sources of our data in Appendix Table A. In Appendix Table B, we then present probit regression results analogous to Tables 4, 5, and 8 in the text. Finally Appendix $C$ report logit regression results where the dependent variable is now TFP growth accelerations and TFP growth recoveries. For accelerations (Tables C1-C2), we find that such episodes are significantly less likely in countries with exceptionally high investment rates (again consistent with the existence of an intensiveversus-extensive-growth tradeoff). Accelerations are more likely in countries with high oldage dependency ratios, for reasons that are not obvious. There is some evidence that accelerations are more likely when economies are more open or growing more open.

Since TFP slumps and accelerations appear to respond to a number of country characteristics in similar ways, it is not surprising that the determinants of TFP growth recoveries (Tables C3-C4) again look broadly similar. We again see a positive coefficient on investment, opposite-signed coefficients on the two dependency rates, and a positive coefficient on the change in openness. 


\section{Appendix Table A. Definitions and Data Sources}

\begin{tabular}{|c|c|c|}
\hline Variables & Description and construction & Data Source \\
\hline Per Capita GDP & $\begin{array}{l}\text { PPP Converted GDP Per Capita (Chain Series), } \\
\text { at } 2005 \text { constant prices }\end{array}$ & $\begin{array}{l}\text { Penn World Tables } 8.1 \\
\text { (cgdpo/pop) }\end{array}$ \\
\hline Total Factor Productivity & TFP at constant national prices $(2005=1)$ & $\begin{array}{l}\text { Penn World Tables } 8.1 \\
\text { (rtfpna) }\end{array}$ \\
\hline Years of Schooling & Average Years of Schooling Attained & Barro and Lee(2014) \\
\hline Investment Share & $\begin{array}{l}\text { Government Consumption Share of PPP } \\
\text { Converted GDP Per Capita at } 2005 \text { constant } \\
\text { prices }\end{array}$ & $\begin{array}{l}\text { Penn World Tables } 8.1 \\
\text { (csh_i) }\end{array}$ \\
\hline $\begin{array}{l}\text { Employment in industry } \\
\text { (\% of total employment) }\end{array}$ & $\begin{array}{l}\text { People who work for a public or private } \\
\text { employer and receive remuneration in wages, } \\
\text { salary, commission, tips, piece rates, or pay in } \\
\text { kind. }\end{array}$ & $\begin{array}{l}\text { World Development } \\
\text { Indicators, World Bank }\end{array}$ \\
\hline $\begin{array}{l}\text { Industry, Value added ( } \% \\
\text { of GDP) }\end{array}$ & $\begin{array}{l}\text { Value of the gross output of producers less the } \\
\text { value of intermediate goods and services } \\
\text { consumed in production, before accounting for } \\
\text { consumption of fixed capital in production }\end{array}$ & $\begin{array}{l}\text { World Development } \\
\text { Indicators, World Bank }\end{array}$ \\
\hline Polity Index & $\begin{array}{l}\text { Polity score captures the regime authority } \\
\text { spectrum on a scale ranging from }-10 \\
\text { (hereditary monarchy) to } 10 \text { (consolidated } \\
\text { democracy). }\end{array}$ & Center for Systemic Peace \\
\hline Rule of Law & Rule of Law: Estimate(WGI) & $\begin{array}{l}\text { World Bank's Worldwide } \\
\text { Governance Indicators }\end{array}$ \\
\hline Real Electricity Cost & $\begin{array}{l}\text { Industrial Electricity Prices including all taxes } \\
\text { first converted to pounds using annual average } \\
\text { exchange rates and then converted to real by } \\
\text { deflating by the UK CPI }\end{array}$ & $\begin{array}{l}\text { International energy price } \\
\text { comparison statistics, } \\
\text { Department of Energy \& } \\
\text { Climate Change, the U.K. }\end{array}$ \\
\hline Real Gas Cost & $\begin{array}{l}\text { Industrial Gas Prices including all taxes first } \\
\text { converted to pounds using annual average } \\
\text { exchange and then converted to real by deflating } \\
\text { by the UK CPI }\end{array}$ & $\begin{array}{l}\text { International energy price } \\
\text { comparison statistics, } \\
\text { Department of Energy \& } \\
\text { Climate Change, the U.K. }\end{array}$ \\
\hline Real oil price & Crude oil prices per barrel in 2014 dollars & $\begin{array}{l}\text { Statistical Review of } \\
\text { World Energy } 2015 \text {, } \\
\text { British Petroleum }\end{array}$ \\
\hline Dependency Ratio, Young & $\begin{array}{l}\text { Percentage ratio of younger dependents } \\
\text { (younger than } 15) \text { to the working-age } \\
\text { population (15-64 years old) }\end{array}$ & $\begin{array}{l}\text { World Development } \\
\text { Indicators } 2014\end{array}$ \\
\hline Dependency Ratio, Old & $\begin{array}{l}\text { Percentage ratio of older dependents (older than } \\
64) \text { to the working-age population }\end{array}$ & $\begin{array}{l}\text { World Development } \\
\text { Indicators } 2014\end{array}$ \\
\hline Trade Openness & $\begin{array}{l}\text { The total trade (exports and imports) as a } \\
\text { percentage of GDP }\end{array}$ & $\begin{array}{l}\text { Penn World Tables } 7.1 \\
\text { (openk) }\end{array}$ \\
\hline Terms of Trade & $\begin{array}{l}\text { Net barter terms of trade index calculated as the } \\
\text { percentage ratio of the export unit value index }\end{array}$ & World Development \\
\hline
\end{tabular}




\begin{tabular}{|c|c|c|}
\hline & $\begin{array}{l}\text { to the import unit value index, measured relative } \\
\text { to the base year } 2000\end{array}$ & Indicators 2014 \\
\hline Real World Trade & $\begin{array}{l}\text { World Merchandise Exports in currency US } \\
\text { dollars deflated by the US CPI. }\end{array}$ & World Trade Organization \\
\hline LIBOR & $\begin{array}{l}\text { 3- month London Interbank Offered Rate, based } \\
\text { on US dollar, year average }\end{array}$ & FRED Economic Data \\
\hline TED spread & TED spread, year average & FRED Economic Data \\
\hline US CPI & US Consumer Price Index, year average & FRED Economic Data \\
\hline UK CPI & UK Consumer Price Index, year average & FRED Economic Data \\
\hline
\end{tabular}


Appendix Table B1. Determinants of TFP Slumps for Countries with Per Capita GDP above \$4,000 (Probit, Consecutive Points)

\begin{tabular}{|c|c|c|c|c|c|c|c|c|c|c|c|c|c|c|c|}
\hline VARIABLES & (1) & (2) & (3) & (4) & $(5)$ & (6) & (7) & (8) & (9) & $(10)$ & (11) & $(12)$ & (13) & (14) & $(15)$ \\
\hline \multirow{2}{*}{ per capita GDP } & 4.787 & 2.994 & 2.435 & 4.523 & 6.853 & $5.475^{*}$ & $12.522 * * *$ & 4.215 & 4.998 & 3.370 & 2.608 & 4.469 & 3.381 & 3.487 & 7.444 \\
\hline & [3.033] & [3.150] & [3.219] & [4.619] & {$[4.626]$} & [3.127] & {$[4.343]$} & [3.149] & [3.550] & [3.133] & [3.182] & {$[3.270]$} & [3.160] & [3.129] & [6.192] \\
\hline \multirow{2}{*}{ per capita GDP square } & -0.256 & -0.169 & -0.141 & -0.247 & -0.360 & $-0.290^{*}$ & $-0.650 * * *$ & -0.232 & -0.271 & -0.186 & -0.147 & -0.245 & -0.187 & -0.192 & -0.396 \\
\hline & {$[0.163]$} & {$[0.170]$} & {$[0.173]$} & {$[0.245]$} & {$[0.243]$} & {$[0.168]$} & [0.229] & {$[0.170]$} & [0.189] & [0.169] & {$[0.171]$} & {$[0.177]$} & [0.171] & [0.169] & {$[0.322]$} \\
\hline \multirow{2}{*}{ years of schooling } & $-0.448 * *$ & & & & & & & & & & & & & & -0.428 \\
\hline & {$[0.211]$} & & & & & & & & & & & & & & {$[0.496]$} \\
\hline \multirow{2}{*}{ change in years of schooling (from $t-5$ to $t$ ) } & & 0.193 & & & & & & & & & & & & & \\
\hline & & {$[5.203]$} & & & & & & & & & & & & & \\
\hline \multirow{2}{*}{ investment rate } & & & $1.760^{* *}$ & & & & & & & & & & & & $2.494^{*}$ \\
\hline & & & [0.833] & & & & & & & & & & & & {$[1.405]$} \\
\hline \multirow[t]{2}{*}{ manufacturing employment share } & & & & 0.007 & & & & & & & & & & & 0.008 \\
\hline & & & & {$[0.016]$} & & & & & & & & & & & {$[0.022]$} \\
\hline \multirow{2}{*}{$\begin{array}{l}\text { change in manufacturing employment share } \\
\text { (from t-5 to t) }\end{array}$} & & & & & $0.483^{* * *}$ & & & & & & & & & & $0.442^{* * *}$ \\
\hline & & & & & {$[0.167]$} & & & & & & & & & & {$[0.171]$} \\
\hline \multirow{2}{*}{ polity2 } & & & & & & $-0.036 * * *$ & & & & & & & & & -0.029 \\
\hline & & & & & & {$[0.010]$} & & & & & & & & & {$[0.030]$} \\
\hline \multirow{2}{*}{ rule of law } & & & & & & & 0.018 & & & & & & & & \\
\hline & & & & & & & {$[0.175]$} & & & & & & & & \\
\hline \multirow{2}{*}{ dependency rate (old) } & & & & & & & & 0.001 & & & & & & & -0.000 \\
\hline & & & & & & & & {$[0.012]$} & & & & & & & {$[0.020]$} \\
\hline \multirow{2}{*}{ dependency rate (young\&old) } & & & & & & & & & 0.004 & & & & & & -0.013 \\
\hline & & & & & & & & & {$[0.005]$} & & & & & & {$[0.016]$} \\
\hline \multirow{2}{*}{ openness } & & & & & & & & & & 0.001 & & & & & -0.002 \\
\hline & & & & & & & & & & {$[0.002]$} & & & & & [0.003] \\
\hline \multirow{2}{*}{ change in openness (from $t-5$ to $t$ ) } & & & & & & & & & & & 0.041 & & & & 0.049 \\
\hline & & & & & & & & & & & [0.027] & & & & {$[0.046]$} \\
\hline \multirow[t]{2}{*}{ undervaluation } & & & & & & & & & & & & -0.054 & & & -0.534 \\
\hline & & & & & & & & & & & & {$[0.203]$} & & & {$[0.437]$} \\
\hline
\end{tabular}


inflation variability

\section{Observations}

1,591

1,520

1,604

840

670

1,585

387

1,443

1,443

1,604

$\begin{array}{lll}1,533 & 1,443 & 1,604 \\ 0.114 & 0.111 & 0.122\end{array}$

[0.161] [0.216]

Pseudo R-squared

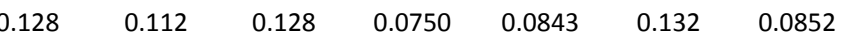

Note: We report probit regression results with year fixed effects included. The dependent variable is a dummy variable that takes the value of 1 for the three years centered on the year when a TFP slowdown begins. We define slowdowns by considering successive 5 year periods and isolating episodes where the growth rate of TFP was at least 1.0 per cent lower on average in the second period than the first. We use the entire string of consecutive years as TFP slowdowns. The sample includes only those countries whose per capita GDP is above U.S. 2005 constant $\$ 4,000$. Oil countries are not included. Numbers in parentheses are robust standard errors. $*$ Statistically significant at the 10 percent level. $* *$ Statistically significant at the 5 percent level. $* *$ Statistically significant at the 1 percent level. 
Appendix Table B2. Determinants of TFP Slumps for Countries whose Per Capita GDP is above \$10,000 (Probit, Consecutive Points)

\begin{tabular}{|c|c|c|c|c|c|c|c|c|c|c|c|c|c|c|c|}
\hline VARIABLES & (1) & (2) & (3) & (4) & (5) & (6) & (7) & (8) & (9) & (10) & (11) & (12) & (13) & (14) & (15) \\
\hline \multirow{2}{*}{ per capita GDP } & -5.251 & -8.442 & -8.867 & -14.277 & -9.424 & -3.193 & -7.372 & -8.393 & -9.239 & -8.166 & -9.545 & -8.659 & -7.318 & -8.243 & -9.400 \\
\hline & {$[8.738]$} & [8.709] & [9.123] & [11.238] & [10.915] & [9.321] & [12.243] & [9.325] & [10.390] & [8.831] & {$[9.018]$} & [9.108] & [8.840] & [8.801] & [14.980] \\
\hline \multirow{2}{*}{ per capita GDP square } & 0.246 & 0.396 & 0.420 & 0.697 & 0.456 & 0.142 & 0.351 & 0.399 & 0.440 & 0.385 & 0.455 & 0.403 & 0.345 & 0.389 & 0.429 \\
\hline & {$[0.442]$} & {$[0.441]$} & {$[0.462]$} & {$[0.571]$} & {$[0.551]$} & {$[0.470]$} & {$[0.610]$} & {$[0.471]$} & {$[0.526]$} & {$[0.448]$} & {$[0.457]$} & {$[0.460]$} & {$[0.447]$} & [0.446] & {$[0.745]$} \\
\hline \multirow{2}{*}{ years of schooling } & $-0.806^{*}$ & & & & & & & & & & & & & & -0.325 \\
\hline & {$[0.453]$} & & & & & & & & & & & & & & {$[0.712]$} \\
\hline \multirow{2}{*}{$\begin{array}{l}\text { change in years of schooling } \\
\text { (from t-5 to t) }\end{array}$} & & -12.784 & & & & & & & & & & & & & \\
\hline & & [10.539] & & & & & & & & & & & & & \\
\hline \multirow{2}{*}{ investment rate } & & & 1.077 & & & & & & & & & & & & 2.114 \\
\hline & & & [1.415] & & & & & & & & & & & & {$[2.243]$} \\
\hline \multirow{2}{*}{ manufacturing employment share } & & & & 0.010 & & & & & & & & & & & -0.014 \\
\hline & & & & {$[0.021]$} & & & & & & & & & & & {$[0.029]$} \\
\hline \multirow{2}{*}{$\begin{array}{l}\text { change in manufacturing employment share } \\
\text { (from } t-5 \text { to } t \text { ) }\end{array}$} & & & & & $0.545^{* *}$ & & & & & & & & & & $0.677^{* *}$ \\
\hline & & & & & {$[0.245]$} & & & & & & & & & & {$[0.282]$} \\
\hline \multirow[t]{2}{*}{ polity2 } & & & & & & $-0.077^{*}$ & & & & & & & & & -0.116 \\
\hline & & & & & & {$[0.041]$} & & & & & & & & & {$[0.083]$} \\
\hline \multirow[t]{2}{*}{ rule of law } & & & & & & & -0.065 & & & & & & & & \\
\hline & & & & & & & {$[0.296]$} & & & & & & & & \\
\hline \multirow{2}{*}{ dependency rate (old) } & & & & & & & & -0.007 & & & & & & & 0.025 \\
\hline & & & & & & & & {$[0.015]$} & & & & & & & {$[0.030]$} \\
\hline \multirow[t]{2}{*}{ dependency rate (young\&old) } & & & & & & & & & -0.001 & & & & & & -0.032 \\
\hline & & & & & & & & & {$[0.010]$} & & & & & & {$[0.021]$} \\
\hline \multirow{2}{*}{ openness } & & & & & & & & & & -0.001 & & & & & -0.004 \\
\hline & & & & & & & & & & [0.003] & & & & & {$[0.005]$} \\
\hline \multirow{2}{*}{ change in openness (from $t-5$ to $t$ ) } & & & & & & & & & & & 0.020 & & & & 0.041 \\
\hline & & & & & & & & & & & {$[0.040]$} & & & & {$[0.080]$} \\
\hline \multirow{2}{*}{ undervaluation } & & & & & & & & & & & & -0.295 & & & $-1.155^{*}$ \\
\hline & & & & & & & & & & & & {$[0.318]$} & & & {$[0.640]$} \\
\hline \multirow[t]{2}{*}{ inflation } & & & & & & & & & & & & & 0.728 & & 3.042 \\
\hline & & & & & & & & & & & & & [1.377] & & [1.894] \\
\hline
\end{tabular}




\begin{tabular}{lccccccccccccccc} 
[0.202] & [0.250] \\
\hline Observations & 799 & 786 & 799 & 529 & 463 & 794 & 236 & 769 & 769 & 799 & 786 & 769 & 799 & 799 & 458 \\
Pseudo R-squared & 0.175 & 0.170 & 0.170 & 0.119 & 0.121 & 0.179 & 0.0903 & 0.169 & 0.169 & 0.169 & 0.168 & 0.170 & 0.169 & 0.169 & 0.160 \\
\hline
\end{tabular}

Note: We report probit regression results with year fixed effects included. The dependent variable is a dummy variable that takes the value of 1 for the three years centered on the year when a TFP slowdown begins. We define slowdowns by considering successive 5 year periods and isolating episodes where the growth rate of TFP was at least 1.0 per cent lower on average in the second period than the first. We use the entire string of consecutive years as TFP slowdowns. The sample includes only those countries whose per capita GDP is above U.S. 2005 constant $\$ 4,000$. Oil countries are not included. Numbers in parentheses are robust standard errors. *Statistically significant at the 10 percent level. ${ }^{*}$ Statistically significant at the 5 percent level. $* * *$ Statistically significant at the 1 percent level. 
Appendix Table B3. The Impact of Global Factors on TFP Slumps (Probit, Consecutive Points)

\begin{tabular}{|c|c|c|c|c|c|c|c|c|c|c|}
\hline \multirow[b]{2}{*}{ VARIABLES } & \multicolumn{5}{|c|}{ countries with per capita gdp above $\$ 4000$} & \multicolumn{5}{|c|}{ countries with per capita gdp above $\$ 10000$} \\
\hline & (1) & (2) & (3) & (4) & (5) & (6) & (7) & (8) & (9) & (10) \\
\hline \multirow{2}{*}{ per capita GDP } & 4.236 & 6.610 & 5.969 & 6.468 & 5.914 & $-10.791 *$ & -19.519 & -20.870 & -21.247 & -21.871 \\
\hline & {$[2.834]$} & {$[6.154]$} & [6.189] & [6.188] & {$[6.216]$} & [5.744] & [13.687] & [13.703] & {$[14.025]$} & [13.971] \\
\hline \multirow{2}{*}{ per capita GDP Square } & -0.231 & -0.355 & -0.320 & -0.349 & -0.318 & $0.522 *$ & 0.953 & 1.026 & 1.035 & 1.073 \\
\hline & [0.153] & {$[0.321]$} & {$[0.323]$} & {$[0.323]$} & {$[0.324]$} & {$[0.293]$} & {$[0.682]$} & {$[0.682]$} & [0.699] & [0.696] \\
\hline \multirow{2}{*}{ years of schooling } & & -0.303 & -0.367 & -0.280 & -0.367 & & -0.400 & -0.630 & -0.214 & -0.504 \\
\hline & & {$[0.466]$} & {$[0.469]$} & {$[0.457]$} & {$[0.460]$} & & {$[0.736]$} & {$[0.736]$} & {$[0.711]$} & {$[0.715]$} \\
\hline \multirow{2}{*}{ investment rate } & & $2.281^{*}$ & 1.973 & $2.227^{*}$ & 1.998 & & 1.638 & 1.272 & 1.328 & 1.094 \\
\hline & & {$[1.358]$} & {$[1.393]$} & [1.349] & {$[1.372]$} & & [2.126] & {$[2.218]$} & [2.131] & [2.194] \\
\hline \multirow{2}{*}{ manufacturing employment share } & & 0.000 & 0.003 & -0.001 & 0.003 & & -0.019 & -0.018 & -0.023 & -0.022 \\
\hline & & {$[0.020]$} & {$[0.020]$} & {$[0.021]$} & {$[0.021]$} & & {$[0.027]$} & {$[0.027]$} & {$[0.028]$} & {$[0.028]$} \\
\hline \multirow{2}{*}{$\begin{array}{l}\text { change in manufacturing employment share } \\
\text { (from } t-5 \text { to } t \text { ) }\end{array}$} & & $0.426^{* *}$ & $0.437^{* *}$ & $0.426^{* *}$ & $0.437^{* *}$ & & $0.655^{* *}$ & $0.710 * * *$ & $0.673^{* * *}$ & $0.724^{* * *}$ \\
\hline & & {$[0.173]$} & {$[0.176]$} & {$[0.173]$} & {$[0.176]$} & & {$[0.257]$} & {$[0.271]$} & {$[0.259]$} & {$[0.273]$} \\
\hline \multirow{2}{*}{ polity2 } & & -0.039 & -0.034 & -0.039 & -0.033 & & -0.095 & -0.096 & -0.100 & -0.100 \\
\hline & & {$[0.031]$} & {$[0.030]$} & {$[0.030]$} & {$[0.030]$} & & {$[0.087]$} & {$[0.088]$} & {$[0.088]$} & {$[0.090]$} \\
\hline \multirow{2}{*}{ dependency rate (old) } & & 0.005 & 0.003 & 0.006 & 0.003 & & 0.025 & 0.021 & 0.030 & 0.024 \\
\hline & & {$[0.021]$} & {$[0.020]$} & {$[0.021]$} & {$[0.020]$} & & {$[0.028]$} & {$[0.027]$} & {$[0.028]$} & {$[0.027]$} \\
\hline \multirow{2}{*}{ dependency rate (young\&old) } & & -0.017 & -0.017 & -0.018 & -0.017 & & -0.034 & -0.033 & $-0.040^{*}$ & $-0.037^{*}$ \\
\hline & & {$[0.015]$} & {$[0.015]$} & {$[0.015]$} & {$[0.015]$} & & {$[0.022]$} & {$[0.022]$} & {$[0.022]$} & {$[0.022]$} \\
\hline \multirow{2}{*}{ openness } & & -0.001 & -0.001 & -0.000 & -0.001 & & -0.002 & -0.002 & -0.001 & -0.002 \\
\hline & & {$[0.003]$} & {$[0.003]$} & [0.003] & {$[0.003]$} & & {$[0.004]$} & {$[0.004]$} & [0.004] & {$[0.004]$} \\
\hline \multirow{2}{*}{ change in openness (from $t-5$ to $t$ ) } & & 0.034 & 0.047 & 0.033 & 0.047 & & 0.018 & 0.044 & 0.009 & 0.038 \\
\hline & & {$[0.044]$} & {$[0.043]$} & [0.043] & {$[0.043]$} & & {$[0.072]$} & {$[0.072]$} & {$[0.070]$} & {$[0.070]$} \\
\hline \multirow{2}{*}{ undervaluation } & & -0.373 & -0.386 & -0.393 & -0.397 & & -0.420 & -0.376 & -0.544 & -0.467 \\
\hline & & {$[0.405]$} & {$[0.414]$} & [0.403] & {$[0.413]$} & & [0.534] & {$[0.570]$} & {$[0.545]$} & {$[0.576]$} \\
\hline \multirow[t]{2}{*}{ inflation } & & 0.250 & 0.044 & 0.296 & 0.124 & & 1.393 & 0.791 & 1.369 & 0.863 \\
\hline & & [1.272] & [1.280] & {$[1.302]$} & [1.301] & & [1.918] & [1.898] & [1.932] & [1.897] \\
\hline \multirow{2}{*}{ inflation variability } & & 0.170 & 0.167 & 0.170 & 0.170 & & $0.377^{*}$ & $0.419^{*}$ & 0.352 & $0.401^{*}$ \\
\hline & & {$[0.214]$} & {$[0.217]$} & {$[0.214]$} & {$[0.218]$} & & {$[0.225]$} & {$[0.241]$} & [0.229] & {$[0.243]$} \\
\hline oil price growth rate & $0.475^{* * *}$ & $0.401^{*}$ & 0.095 & $0.408^{*}$ & 0.115 & $0.663^{* * *}$ & $0.469 *$ & 0.038 & $0.473^{*}$ & 0.064 \\
\hline
\end{tabular}




\begin{tabular}{|c|c|c|c|c|c|c|c|c|c|}
\hline \multirow[t]{7}{*}{ [0.131] } & {$[0.214]$} & {$[0.234]$} & {$[0.208]$} & {$[0.220]$} & [0.179] & {$[0.265]$} & [0.293] & {$[0.254]$} & {$[0.268]$} \\
\hline & 0.012 & 0.024 & & & & 0.010 & 0.024 & & \\
\hline & [0.038] & {$[0.040]$} & & & & [0.049] & [0.053] & & \\
\hline & & $2.688 * * *$ & & $2.583^{* * *}$ & & & $3.488^{* * *}$ & & $3.346^{* * *}$ \\
\hline & & [0.967] & & {$[0.894]$} & & & {$[1.223]$} & & [1.117] \\
\hline & & & 0.169 & 0.174 & & & & 0.384 & 0.363 \\
\hline & & & {$[0.255]$} & {$[0.257]$} & & & & {$[0.317]$} & {$[0.322]$} \\
\hline 1,604 & 649 & 649 & 649 & 649 & 847 & 460 & 460 & 460 & 460 \\
\hline 0.0117 & 0.0768 & 0.0865 & 0.0776 & 0.0867 & 0.0350 & 0.0896 & 0.105 & 0.0939 & 0.108 \\
\hline
\end{tabular}

world trade growth rate

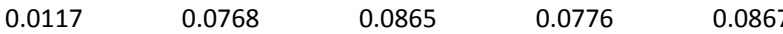

$0.0350 \quad 0.089$

Note: We report probit regression results with year fixed effects included. The dependent variable is a dummy variable that takes the value of 1 for the three years centered on
the year when a TFP slowdown begins. We define slowdowns by considering successive 5 year periods and isolating episodes where the growth rate of TFP was at least 1.0 per cent lower on average in the second period than the first. We use the entire string of consecutive years as TFP slowdowns. The sample includes only those countries

whose per capita GDP is above U.S. 2005 constant \$4,000 (columns 1-5) and only those with per capita GDP is above U.S. 2005 constant \$10,000 (columns 6-10). Real oil price is crude oil price per barrel in 2014 dollars, collected from Statistical Review of World Energy 2015. Real world trade is world trade in merchandise in current US

dollars, collected from WTO and then deflated by the US CPI. The data for LIBOR and TED spread start from 1986. Oil countries are not included. Numbers in parentheses

are robust standard errors. *Statistically significant at the 10 percent level. **Statistically significant at the 5 percent level. ***Statistically significant at the 1 percent level. 
Appendix Table C1. Determinants of TFP Accelerations for Countries with Per Capita GDP above \$4,000 (Logit, Consecutive Points)

\begin{tabular}{|c|c|c|c|c|c|c|c|c|c|c|c|c|c|c|}
\hline VARIABLES & (1) & (2) & (3) & (4) & (5) & (6) & (7) & (8) & (9) & (10) & (11) & (12) & (13) & (14) \\
\hline \multirow{2}{*}{ per capita GDP } & 8.265 & $8.872^{*}$ & $19.007^{* * *}$ & 9.404 & 9.336 & 111.689* & $18.192^{* * *}$ & $22.550^{* * *}$ & $9.276^{*}$ & 8.639 & $14.623^{* *}$ & $9.221^{*}$ & $18.056^{* *}$ & $620.071^{* * *}$ \\
\hline & [5.993] & [5.336] & [5.666] & [18.546] & [5.789] & [58.204] & [6.204] & [6.574] & [5.290] & [5.343] & [5.954] & [5.324] & [8.514] & [198.215] \\
\hline \multirow{2}{*}{ per capita GDP square } & $-0.677^{* *}$ & $-0.713^{* *}$ & $-1.241 * * *$ & -1.400 & $-0.728 * *$ & $-7.387^{* *}$ & $-1.263 * * *$ & $-1.491 * * *$ & $-0.733^{* *}$ & $-0.701 * *$ & $-1.039 * * *$ & $-0.728 * *$ & $-1.250 * * *$ & $-35.609 * * *$ \\
\hline & {$[0.323]$} & {$[0.288]$} & [0.304] & [0.990] & {$[0.310]$} & [3.292] & {$[0.339]$} & {$[0.360]$} & {$[0.285]$} & [0.288] & [0.324] & [0.287] & [0.462] & [11.092] \\
\hline \multirow{2}{*}{ years of schooling } & 0.317 & & & & & & & & & & & & & 5.790 \\
\hline & [0.908] & & & & & & & & & & & & & [20.245] \\
\hline \multirow{2}{*}{ change in years of schooling (from t- 5 to $t$ ) } & & -0.217 & & & & & & & & & & & & \\
\hline & & [10.177] & & & & & & & & & & & & \\
\hline \multirow{2}{*}{ investment rate } & & & $-11.689 * * *$ & & & & & & & & & & & $-115.462 * * *$ \\
\hline & & & {$[1.990]$} & & & & & & & & & & & [38.036] \\
\hline \multirow{2}{*}{ manufacturing employment share } & & & & & & & & & & & & & & $-1.024^{*}$ \\
\hline & & & & & & & & & & & & & & [0.572] \\
\hline \multirow{2}{*}{$\begin{array}{l}\text { change in manufacturing employment share } \\
\text { (from t-5 to } t \text { ) }\end{array}$} & & & & -0.275 & & & & & & & & & & $5.647^{* *}$ \\
\hline & & & & [0.332] & & & & & & & & & & [2.463] \\
\hline \multirow{2}{*}{ polity2 } & & & & & -0.003 & & & & & & & & & 0.038 \\
\hline & & & & & {$[0.026]$} & & & & & & & & & {$[0.513]$} \\
\hline \multirow{2}{*}{ rule of law } & & & & & & 2.087 & & & & & & & & \\
\hline & & & & & & {$[2.398]$} & & & & & & & & \\
\hline \multirow{2}{*}{ dependency rate (old) } & & & & & & & $0.193 * * *$ & & & & & & & $3.078^{* *}$ \\
\hline & & & & & & & {$[0.065]$} & & & & & & & [1.364] \\
\hline \multirow{2}{*}{ dependency rate (young\&old) } & & & & & & & & $0.058^{* * *}$ & & & & & & -0.328 \\
\hline & & & & & & & & {$[0.020]$} & & & & & & {$[0.277]$} \\
\hline \multirow{2}{*}{ openness } & & & & & & & & & 0.002 & & & & & $0.234^{* *}$ \\
\hline & & & & & & & & & {$[0.006]$} & & & & & {$[0.111]$} \\
\hline \multirow{2}{*}{ change in openness (from $t-5$ to $t$ ) } & & & & & & & & & & 0.027 & & & & 0.103 \\
\hline & & & & & & & & & & {$[0.045]$} & & & & [0.502] \\
\hline \multirow{2}{*}{ undervaluation } & & & & & & & & & & & -0.368 & & & $15.962^{* *}$ \\
\hline & & & & & & & & & & & [0.548] & & & [7.086] \\
\hline inflation & & & & & & & & & & & & 0.066 & & 12.879 \\
\hline
\end{tabular}




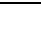

1,70

704

$\begin{array}{cc}605 & 1,683 \\ 0.541 & 0.279\end{array}$

245

1,534

1,534

1,704

1,633
0.274

$\begin{array}{llllllllll}0.283 & 0.274 & 0.311 & 0.541 & 0.279 & 0.695 & 0.292 & 0.292 & 0.283 & 0.274\end{array}$

Note: We report logit regression results with year and country fixed effects included. The dependent variable is a dummy variable that takes the value of 1 was at least 1.0 per cent higher on average in the second period than the first. We use the entire string of consecutive years as TFP accelerations. The sample includes only those countries whose per capita GDP is above U.S. 2005 constant $\$ 4,000$. Oil countries are not included. *Statistically significant at the 10 percent level. **Statistically significant at the 5 percent level. ***Statistically significant at the 1 percent level. 
Appendix Table C2. Determinants of TFP Accelerations for Countries with Per Capita GDP above \$10,000 (Logit, Consecutive Points)

\begin{tabular}{|c|c|c|c|c|c|c|c|c|c|c|c|c|c|c|}
\hline VARIABLES & (1) & (2) & (3) & (4) & (5) & (6) & (7) & (8) & (9) & (10) & (11) & (12) & (13) & (14) \\
\hline \multirow{2}{*}{ per capita GDP } & 18.284 & 40.485 & 28.485 & $171.455^{* * *}$ & $194.181^{* * *}$ & 5.781 & 421.732 & $45.471^{*}$ & $50.971 *$ & 33.386 & 31.554 & 36.420 & 20.174 & 34.117 \\
\hline & [25.597] & [25.793] & [25.363] & [43.739] & [65.699] & [26.017] & [337.135] & [26.691] & [26.591] & [26.402] & [24.881] & [27.818] & [25.917] & [32.044] \\
\hline \multirow{2}{*}{ per capita GDP square } & -1.397 & $-2.478^{*}$ & -1.898 & $-9.826 * * *$ & $-11.236 * * *$ & -0.673 & -26.701 & $-2.813^{* *}$ & $-3.078^{* *}$ & -2.126 & -2.031 & -2.359 & -1.456 & -2.260 \\
\hline & [1.321] & [1.338] & [1.310] & [2.296] & [3.483] & [1.350] & [20.437] & {$[1.391]$} & [1.385] & [1.367] & [1.291] & [1.438] & {$[1.340]$} & [1.680] \\
\hline \multirow{2}{*}{ years of schooling } & $5.354^{* *}$ & & & & & & & & & & & & & \\
\hline & [2.534] & & & & & & & & & & & & & \\
\hline \multirow{2}{*}{ change in years of schooling (from $t-5$ to $t$ ) } & & $59.685^{* *}$ & & & & & & & & & & & & \\
\hline & & [24.578] & & & & & & & & & & & & \\
\hline \multirow{2}{*}{ investment rate } & & & $-21.753 * * *$ & & & & & & & & & & & \\
\hline & & & {$[4.037]$} & & & & & & & & & & & \\
\hline \multirow{2}{*}{ manufacturing employment share } & & & & $-0.243^{*}$ & & & & & & & & & & \\
\hline & & & & {$[0.141]$} & & & & & & & & & & \\
\hline \multirow{2}{*}{$\begin{array}{l}\text { change in manufacturing employment share } \\
\text { (from t-5 to } t \text { ) }\end{array}$} & & & & & $-1.176^{*}$ & & & & & & & & & \\
\hline & & & & & {$[0.600]$} & & & & & & & & & \\
\hline \multirow[t]{2}{*}{ polity2 } & & & & & & $1.472^{* * *}$ & & & & & & & & \\
\hline & & & & & & {$[0.493]$} & & & & & & & & \\
\hline \multirow[t]{2}{*}{ rule of law } & & & & & & & 20.981 & & & & & & & \\
\hline & & & & & & & {$[15.019]$} & & & & & & & \\
\hline \multirow{2}{*}{ dependency rate (old) } & & & & & & & & 0.137 & & & & & & \\
\hline & & & & & & & & [0.091] & & & & & & \\
\hline \multirow[t]{2}{*}{ dependency rate (young\&old) } & & & & & & & & & 0.037 & & & & & \\
\hline & & & & & & & & & {$[0.037]$} & & & & & \\
\hline \multirow{2}{*}{ openness } & & & & & & & & & & -0.000 & & & & \\
\hline & & & & & & & & & & {$[0.018]$} & & & & \\
\hline \multirow{2}{*}{ change in openness (from $t-5$ to $t$ ) } & & & & & & & & & & & -0.018 & & & \\
\hline & & & & & & & & & & & {$[0.108]$} & & & \\
\hline \multirow{2}{*}{ undervaluation } & & & & & & & & & & & & -1.353 & & \\
\hline & & & & & & & & & & & & [1.145] & & \\
\hline inflation & & & & & & & & & & & & & -6.437 & \\
\hline
\end{tabular}




876

889

487

375

884

90

852

852

889

876

852
0.340

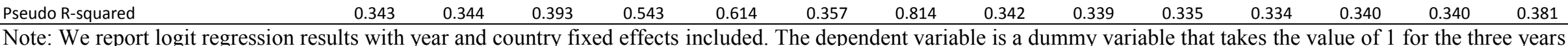
centered on the year when a TFP acceleration begins. We define accelerations by considering successive 5 year periods and isolating episodes where the growth rate of TFP was at least 1.0 per cent higher on average in the second period than the first. We use the entire string of consecutive years as TFP accelerations. The sample includes only those countries whose per capita GDP is above U.S. 2005 constant $\$ 10,000$. Oil countries are not included. *Statistically significant at the 10 percent level. **Statistically significant at the 5 percent level. ***Statistically significant at the 1 percent leve 
Appendix Table C3. Determinants of TFP Recoveries for Countries with Per Capita GDP above \$4,000 (Logit, Consecutive Points)

\begin{tabular}{|c|c|c|c|c|c|c|c|c|c|c|c|c|c|}
\hline VARIABLES & (1) & (2) & (3) & (4) & (5) & (6) & (7) & (8) & (9) & (10) & (11) & $(12)$ & (13) \\
\hline \multirow{2}{*}{ per capita GDP } & $26.085^{* * *}$ & $18.265^{* * *}$ & $29.118^{* * *}$ & 10.401 & $22.543 * * *$ & $27.352^{* * *}$ & $33.009 * * *$ & $18.166^{* * *}$ & $17.593 * * *$ & $21.130 * * *$ & $17.925 * * *$ & $26.923 * * *$ & $482.712^{* * *}$ \\
\hline & [6.793] & {$[5.910]$} & {$[6.353]$} & [18.310] & [6.611] & [6.688] & [7.059] & [5.858] & [5.899] & [6.151] & [5.878] & [9.808] & [141.828] \\
\hline \multirow{2}{*}{ per capita GDP square } & $-1.653 * * *$ & $-1.232 * * *$ & $-1.788^{* * *}$ & -1.441 & $-1.449 * * *$ & $-1.758^{* * *}$ & $-2.045 * * *$ & $-1.229 * * *$ & $-1.194 * * *$ & $-1.380 * * *$ & $-1.209 * * *$ & $-1.774 * * *$ & $-28.015^{* * *}$ \\
\hline & {$[0.370]$} & [0.322] & [0.344] & {$[0.978]$} & {$[0.358]$} & [0.368] & [0.387] & [0.319] & [0.321] & [0.337] & {$[0.320]$} & [0.538] & [7.940] \\
\hline \multirow{2}{*}{ years of schooling } & $-2.569 * * *$ & & & & & & & & & & & & 11.807 \\
\hline & [0.995] & & & & & & & & & & & & [19.658] \\
\hline \multirow{2}{*}{ change in years of schooling (from $t-5$ to $t$ ) } & & 6.448 & & & & & & & & & & & \\
\hline & & [10.657] & & & & & & & & & & & \\
\hline \multirow{2}{*}{ investment rate } & & & $-12.555^{* * *}$ & & & & & & & & & & $-95.262^{* * *}$ \\
\hline & & & {$[2.165]$} & & & & & & & & & & [28.150] \\
\hline \multirow{2}{*}{ manufacturing employment share } & & & & & & & & & & & & & $-0.880^{*}$ \\
\hline & & & & & & & & & & & & & [0.453] \\
\hline \multirow{2}{*}{$\begin{array}{l}\text { change in manufacturing employment share } \\
\text { (from } t-5 \text { to } t \text { ) }\end{array}$} & & & & -0.157 & & & & & & & & & $4.391^{* *}$ \\
\hline & & & & {$[0.341]$} & & & & & & & & & [1.743] \\
\hline \multirow{2}{*}{ polity2 } & & & & & -0.044 & & & & & & & & 0.310 \\
\hline & & & & & {$[0.028]$} & & & & & & & & {$[0.371]$} \\
\hline \multirow[t]{2}{*}{ dependency rate (old) } & & & & & & $0.263^{* * *}$ & & & & & & & $2.980 * *$ \\
\hline & & & & & & [0.069] & & & & & & & {$[1.160]$} \\
\hline \multirow{2}{*}{ dependency rate (young\&old) } & & & & & & & $0.078^{* * *}$ & & & & & & -0.155 \\
\hline & & & & & & & {$[0.021]$} & & & & & & {$[0.251]$} \\
\hline \multirow{2}{*}{ openness } & & & & & & & & 0.008 & & & & & $0.171^{* *}$ \\
\hline & & & & & & & & {$[0.007]$} & & & & & {$[0.085]$} \\
\hline \multirow{2}{*}{ change in openness (from t-5 to t) } & & & & & & & & & 0.033 & & & & 0.315 \\
\hline & & & & & & & & & {$[0.048]$} & & & & {$[0.406]$} \\
\hline \multirow[t]{2}{*}{ undervaluation } & & & & & & & & & & -0.350 & & & \\
\hline & & & & & & & & & & [0.593] & & & \\
\hline \multirow{2}{*}{ inflation } & & & & & & & & & & & 0.623 & & $26.393^{*}$ \\
\hline & & & & & & & & & & & [1.318] & & [14.723] \\
\hline inflation variability & & & & & & & & & & & & 1.273 & $7.222^{*}$ \\
\hline
\end{tabular}




\begin{tabular}{|c|c|c|c|c|c|c|c|c|c|c|c|c|c|}
\hline & & & & & & & & & & & & [1.196] & {$[4.278]$} \\
\hline Observations & 1,649 & 1,581 & 1,649 & 578 & 1,628 & 1,486 & 1,486 & 1,649 & 1,581 & 1,486 & 1,649 & 975 & 340 \\
\hline Pseudo R-squared & 0.306 & 0.289 & 0.332 & 0.526 & 0.298 & 0.297 & 0.296 & 0.302 & 0.289 & 0.284 & 0.301 & 0.358 & 0.793 \\
\hline
\end{tabular}

Note: We report logit regression results with year and country fixed effects included. The dependent variable is a dummy variable that takes the value of 1 for the three years the entire string of consecutive years as TFP accelerations. The sample includes only those countries whose per capita GDP is above U.S. 2005 constant $\$ 4,000$. Oil countries are not included. *Statistically significant at the 10 percent level. **Statistically significant at the 5 percent level. ***Statistically significant at the 1 percent level 
Appendix Table C4. Determinants of TFP Recoveries for Countries with Per Capita GDP above \$10,000 (Logit, Consecutive Points)

\begin{tabular}{|c|c|c|c|c|c|c|c|c|c|c|c|c|c|}
\hline VARIABLES & (1) & (2) & (3) & (4) & (5) & (6) & (7) & (8) & (9) & (10) & (11) & (12) & (13) \\
\hline \multirow{2}{*}{ per capita GDP } & $67.093 * *$ & $93.546^{* * *}$ & $79.282 * * *$ & $200.196 * * *$ & $47.416^{*}$ & 713.114 & $71.182 * * *$ & $81.232 * * *$ & $75.192 * * *$ & $74.541 * * *$ & $65.494^{* *}$ & $72.246^{* *}$ & $62.671^{*}$ \\
\hline & [27.708] & [28.580] & [28.342] & [64.993] & [27.790] & [621.966] & [27.493] & [27.564] & [28.778] & [26.750] & [28.271] & [28.427] & [32.642] \\
\hline \multirow{2}{*}{ per capita GDP square } & $-3.943 * * *$ & $-5.263 * * *$ & $-4.577 * * *$ & $-11.484 * * *$ & $-2.865^{* *}$ & -40.302 & $-4.142^{* * *}$ & $-4.636^{* * *}$ & $-4.337^{* * *}$ & $-4.303^{* * *}$ & $-3.850 * * *$ & $-4.186 * * *$ & $-3.736^{* *}$ \\
\hline & [1.440] & [1.493] & [1.479] & {$[3.436]$} & {$[1.450]$} & {$[33.851]$} & [1.436] & {$[1.436]$} & [1.499] & [1.397] & {$[1.466]$} & [1.482] & {$[1.716]$} \\
\hline \multirow{2}{*}{ years of schooling } & 2.984 & & & & & & & & & & & & \\
\hline & {$[2.620]$} & & & & & & & & & & & & \\
\hline \multirow{2}{*}{ change in years of schooling (from $t-5$ to $t$ ) } & & $82.324 * * *$ & & & & & & & & & & & \\
\hline & & [26.389] & & & & & & & & & & & \\
\hline \multirow[t]{2}{*}{ investment rate } & & & $-23.952 * * *$ & & & & & & & & & & \\
\hline & & & {$[4.323]$} & & & & & & & & & & \\
\hline \multirow{2}{*}{$\begin{array}{l}\text { change in manufacturing employment share } \\
\text { (from } \mathrm{t}-5 \text { to } \mathrm{t} \text { ) }\end{array}$} & & & & $-1.259 * *$ & & & & & & & & & \\
\hline & & & & {$[0.597]$} & & & & & & & & & \\
\hline \multirow[t]{2}{*}{ polity2 } & & & & & $1.722^{* * *}$ & & & & & & & & \\
\hline & & & & & {$[0.641]$} & & & & & & & & \\
\hline \multirow[t]{2}{*}{ rule of law } & & & & & & 5.163 & & & & & & & \\
\hline & & & & & & {$[5.830]$} & & & & & & & \\
\hline \multirow[t]{2}{*}{ dependency rate (old) } & & & & & & & $0.161^{*}$ & & & & & & \\
\hline & & & & & & & [0.092] & & & & & & \\
\hline \multirow[t]{2}{*}{ dependency rate (young\&old) } & & & & & & & & $0.072^{*}$ & & & & & \\
\hline & & & & & & & & [0.039] & & & & & \\
\hline \multirow[t]{2}{*}{ openness } & & & & & & & & & 0.002 & & & & \\
\hline & & & & & & & & & {$[0.019]$} & & & & \\
\hline \multirow[t]{2}{*}{ change in openness (from $t-5$ to $t$ ) } & & & & & & & & & & 0.054 & & & \\
\hline & & & & & & & & & & {$[0.107]$} & & & \\
\hline \multirow[t]{2}{*}{ undervaluation } & & & & & & & & & & & -0.928 & & \\
\hline & & & & & & & & & & & [1.146] & & \\
\hline \multirow[t]{2}{*}{ inflation } & & & & & & & & & & & & -1.658 & \\
\hline & & & & & & & & & & & & [4.121] & \\
\hline inflation variability & & & & & & & & & & & & & 1.580 \\
\hline
\end{tabular}



centered on the year when a TFP recovery begins. We define a recovery if an accelerations followed a slowdown based on the 5 year - 1 per cent threshold citeron. We use the entire string of consecutive years as TFP accelerations. The sample includes only those countries whose per capita GDP is above U.S. 2005 constant $\$ 10,000$. Oil

countries are not included. *Statistically significant at the 10 percent level. **Statistically significant at the 5 percent level. ***Statistically significant at the 1 percent level. 